\title{
BEYOND BELIEF: HOW THE "CORROBORATION RULE" IN MALAWI OBSTRUCTS JUSTICE FOR VICTIMS OF SEX CRIMES AND DISCRIMINATES AGAINST WOMEN AND GIRLS ON THE BASIS OF SEX-A CALL FOR LEGISLATIVE CHANGE
}

\author{
MICHELLE XIAO LIU \& ALEXANDRA K. CREEL BENTON*
}

\section{Abstract}

Sexual abuse against women and girls in Malawi is pervasive, and survivors face significant barriers in their quest for justice. One particular barrier-the "corroboration rule"- stands out as a discriminatory and onerous roadblock for women and girls who seek justice as victims of sex crimes.

The corroboration rule is a common law rule of evidence and criminal procedure that requires prosecutors trying sex offence cases to have independent evidence in addition to a victim's testimony, even if that testimony is credible and shows beyond a reasonable doubt that the defendant committed the sex crime. This heightened evidentiary standard for victims of sex crimes is based on the stereotype that women and girls are apt to lie about being raped and that their word alone - no matter how clear, convincing, or

\footnotetext{
* This human rights report was authored by Michelle Xiao Liu (J.D., LL.M.), the Supervising Attorney \& Teaching Fellow of the International Women's Human Rights Clinic ("IWHRC" or the "Clinic") at Georgetown University Law Center from 2018 to 2020, and Alexandra K. Creel Benton (J.D.), an IWHRC Student Advocate during the Fall 2019 semester. The report is the result of a partnership between Michelle Xiao Liu, four IWHRC Student Advocates (Allison Carlon, Mariame Dangnokho, Amy Uihlein, and Darya Vakulenko), and Immaculate Maluza, Vice President of the Women Lawyers Association of Malawi. The authors wish to acknowledge Asees Bhasin, DaNia Henry, Eric Holleran, and Jade Zhong, the other four IWHRC Student Advocates who also participated in the human rights fact-finding trip. The authors also wish to acknowledge Kathryn Priester, another IWHRC Student Advocate, who conducted substantial research on the history of the corroboration rule and its impacts on female survivors of sexual crimes. The report benefited from valuable feedback given by Professor Susan Deller Ross, the Founder and Director of the IWHRC. The authors would like to thank the Clinic's other Malawian partners: Clara Lungu, the National Director of Women and Law in Southern Africa-Malawi ("WLSA Malawi"), and Godfrey Dalitso Kangaude, a scholar on gender and adolescent sexuality, human rights, and law in Malawi. The authors would also like to thank the U.S. supervisors (Michelle Gulino and Nina Sudhakar) and the Malawi supervisors (Immaculate Maluza, Chifundo Chulu, Hillary Tembo, Modestar Kaso, Clara Lungu, Titani Magalasi, Chisomo Magwejani, Benjamin Msutu, and Angali Chagwamnjira) who accompanied the Student Advocates on their interviews in Malawi. The authors wish to thank Anna Harty, the IWHRC Office Manager, for coordinating the fact-finding trip and supporting the work of the Clinic.
} 
credible - should not be enough to put a rapist behind bars. Because of the rule, too many women and girls in Malawi are not treated equally in the criminal justice system, and rarely are those who sexually abuse them brought to justice in court. This fosters a climate of impunity for rapists and sexual abusers.

While many countries around the world used to require the corroboration rule in sexual offences, in the modern era, Malawi stands apart from the rest of the world as one of the few countries that still requires its use as a matter of common law. However, with a constitution that guarantees equality for women and girls and equal access to justice under the law, and as a State Party to treaties that guarantee the same, Malawi's Parliament should abolish the corroboration rule.

\section{INTRODUCTION}

Sexual violence against women and girls in Malawi is pervasive. According to a United Nations report, $25.3 \%$ of all women and girls age fifteen to forty-nine in Malawi have experienced sexual violence at least once in their lifetime. ${ }^{1}$ A 2013 national survey on sexual violence against children also found that one in every five young women had experienced at least one incident of sexual violence prior to age eighteen, and one in three of these girls who had a sexual encounter prior to age eighteen "were forced or coerced to engage in sexual intercourse." " Of those females who were victims of sexual abuse prior to age eighteen, $68.4 \%$ reported multiple incidents. ${ }^{3}$ Furthermore, buttressed by beliefs in stereotypes and biases about women, survivors are "all too often assumed to be lying or seeking revenge, and are blamed for the violence they've experienced." ${ }^{\prime}$ It is a commonly held belief in Malawi, and specifically a common belief of those involved in the criminal justice system, that "women pretend to be refusing [sex] when actually they want what

\footnotetext{
${ }^{1}$ Dep't of Econ. and Soc. Affs., Stat. Div., The World's Women 2015: Trends and Statistics, Fig. 6.3, U.N. Doc. ST/ESA/STAT/SER.K/20 (2015),

https://unstats.un.org/unsd/gender/downloads/worldswomen2015_report.pdf [https://perma.cc/NB39-3C7Y] (showing proportion of women aged fifteen to forty-nine years experiencing sexual violence (irrespective of the perpetrator) at least once in their lifetime and in the last twelve months, 1995-2013).

${ }^{2}$ Republic of Malawi, Ministry of Gender, Child., Disability \& Soc. Welfare, Violence Against Children and Young Women in Malawi: Findings From a NATional Survey 2013, at 23 (2014) [hereinafter ViolenCE AGAINST CHILDREN SURVEY], https://www.togetherforgirls.org/wpcontent/uploads/2017/10/MLW_resources_violencereport_final.pdf [https://perma.cc/S36Q-NNEM].

${ }^{3} I d$.

${ }^{4}$ Challenging the Corroboration Rule, WLSA MaLAWI (May 20, 2016), https://wlsamalawi.com/2016/05/20/blog-post-title-2/.
} 
they are refusing ... and most of the time when a woman says 'no' she actually means 'yes."

Against this backdrop, survivors of sexual abuse face substantial social and systemic barriers in reporting incidents to police, aiding prosecutors in bringing a criminal case against an alleged offender, and seeing that alleged offender be brought to justice through the courts. A 2019 UNICEF report that examined the lived experiences of women and girl survivors of sexual violence in Blantyre, Lilongwe, and Mzuzu found such barriers to be deeply embedded in the Malawi criminal justice system. ${ }^{6}$ Indeed, of the 138 incidents of sexual violence that were tracked in the study, only one percent of the perpetrators (that is, fourteen persons) faced conviction. ${ }^{7}$

One barrier in particular - the corroboration rule — stands out in the Malawi criminal justice system as a significant legal impediment to survivors of sexual abuse who seek justice. The corroboration rule is based on a gender stereotype and contributes to the prevalence of rape culture in Malawi. The corroboration rule is a common law rule of evidence and criminal procedure that requires prosecutors trying sex offence cases to have independent evidence in addition to a victim's testimony, even if that testimony is credible and proves, beyond a reasonable doubt, that the defendant committed the sex

\footnotetext{
${ }^{5}$ Bernadette Wangisa Malunga, 'Remember Potipher's Wife': The 'Rule' on Corroboration in Rape and Defilement Offences. A Systematic Violation of the Rights of Women and Girls in Malawi 54 (2010) (Master's Degree thesis, University of Zimbabwe), http://www.searcwl.ac.zw/index.php?option=com_docman\&task=doc_download\&gid=112\&Itemid=96 [https://perma.cc/ZL87-WYT9].

${ }^{6}$ UNICEF, Access to Criminal Justice Services: The Case of Survivors of Sexual Violence in MALAWI 32-33 (2019) [hereinafter UNICEF ACCESS to JustiCE REPORT], https://www.unicef.org/malawi/media/1931/file/The\%20case\%20of\%20survivors\%20of\%20sexual\%20viole nce\%20in\%20Malawi.pdf [https://perma.cc/459Y-S5V8]. Some of the reasons why perpetrators were released (or escaped arrest altogether) included: the perpetrator is rich and the survivor is poor; the police asked for gas money from survivors in order to go and make an arrest (and the survivors did not have any money to give); the perpetrator paid money to the police to avoid arrest; the survivor lacked a medical report showing sexual activity; a medical examination showed no sexually transmitted infection or pregnancy; the perpetrator or his family apologized for the wrongdoing; the perpetrator or his family paid some financial compensation to the survivor's family; the survivor's family decided to forgive the perpetrator and/or was pressured by community members to drop the charge. $I d$.
}

${ }^{7} I d$. at 32 . 
crime. ${ }^{8}$ This heightened evidentiary standard for victims of sex crimes is based on the stereotype that women and girls are prone to lie about being raped and that their word alone - no matter how clear, convincing, or credible - should not be enough to put a rapist behind bars. ${ }^{9}$ Women's rights advocates argue that the corroboration rule in sexual offence cases creates roadblocks for prosecutors and discourages law enforcement from performing diligent investigations into reported cases - manifesting a culture of impunity for sexual predators. ${ }^{10}$ The continued use of the rule communicates to sexual abusers that they are unlikely to face negative consequences for the heinous sexual acts that they commit against women and girls. ${ }^{11}$

This report examines the significant ways that the corroboration rule imposes a discriminatory evidentiary burden for female survivors and obstructs their access to justice. Part I outlines the research and fact-finding processes that the International Women's Human Rights Clinic ("IWHRC" or the "Clinic") undertook, together with its partner-Women Lawyers Association of Malawi-to prepare this report. Part II gives the definition and historical background of the corroboration rule. Part III explains the legal framework of the rights of women and girls to equality and access to justice for sexual crimes committed against them. It outlines the obligations that Malawi has under international human rights treaties and its constitution to implement these rights through legislation. Part IV argues that the corroboration rule violates women's and girls' right to access to justice under the constitution and international human rights law. Part $\mathrm{V}$ argues that the corroboration rule discriminates against women and girls on the basis of sex and violates their right to equality and non-discrimination under the constitution and international human rights law. Part VI urges the Malawi Parliament to abolish the use of

\footnotetext{
${ }^{8}$ See Mariette v. Republic [1966] 4 ALR Malawi Series 119 (High Ct.) (Malawi). The government of Malawi has said that the rule is required in sexual offence cases as a matter of practice. Comm. on the Elimination of Discrimination Against Women ("CEDAW Committee"), Replies of Malawi to the List of Issues and Questions with Regard to the Consideration of the Seventh Periodic Report of Malawi, $\uparrow$ 25, U.N. Doc. CEDAW/C/MWI/Q/7/Add.1 (July 21, 2015) [hereinafter CEDAW Committee, Replies of Malawi], https://digitallibrary.un.org/record/803353/files/CEDAW_C_MWI_Q_7_Add.1-EN.pdf [https://perma.cc/55SW-5YRS].

${ }^{9}$ Sir Matthew Hale, The History of the Pleas of the Crown 634 (1st Am. Ed. 1847).

${ }^{10}$ Challenging the Corroboration Rule, supra note 4.

${ }^{11} I d$.
} 
the corroboration rule in sexual offences by enacting an amendment to the Criminal Procedure and Evidence Code. ${ }^{12}$

\section{Methodology}

The International Women's Human Rights Clinic at Georgetown University Law Center, in partnership with Women Lawyers Association of Malawi, collaborated on this report aimed at understanding how the corroboration rule, which is required only for sexual offence cases, impacts a survivor's ability to obtain justice and equal treatment in the criminal justice system.

The Clinic faculty and student advocates conducted extensive research on the rights to access justice and equality guaranteed by the Constitution of Malawi, as well as the rights enshrined in various international and regional treaties to which Malawi is a State Party. To supplement their understanding of the global trends in legislation relating to the corroboration rule, the Clinic faculty and student advocates researched numerous comparative jurisdictions around the world.

From the $9^{\text {th }}$ to the $13^{\text {th }}$ of March 2020, the Clinic team travelled to Malawi to conduct an intensive fact-finding investigation in Lilongwe, Blantyre, and Zomba. ${ }^{13}$ The Clinic faculty and student advocates interviewed over seventy stakeholders, including affected persons, community leaders, lawmakers, magistrates and judges, law enforcement personnel, government officials, women's and children's rights advocates, teachers, academics, health professionals, leaders of non-governmental organizations and international organizations, and other experts on the subject. ${ }^{14}$ Lawyers and paralegals

\footnotetext{
${ }^{12}$ Criminal Procedure and Evidence Code, No. 14 (2010) (Malawi)

https://malawilii.org/mw/consolidated_legislation/801 [https://perma.cc/Q4KN-5JEW].

${ }^{13}$ The Clinic faculty designed this mission in accordance with the International Human Rights Fact-Finding Guidelines (The Lund-London Guidelines) that were developed by the International Bar Association's Human Rights Institute and the Raoul Wallenberg Institute. See generally InT'L BAR Ass'N, The LundLondon Guidelines (2009), https://www.ibanet.org/Fact_Finding_Guidelines.aspx [https://perma.cc/BF7BBCA7]. The research protocol was approved by the Georgetown University Institutional Review Board and the Malawi National Committee on Research Ethics in Social Sciences and Humanities (NCRSH).
}

${ }^{14}$ To protect interviewees, Clinic faculty and student advocates implemented an extensive informed consent process. Interviewees were informed that no direct benefit would arise from their participation in the interview and no harm would come to them if they chose not to participate. Additionally, all interviews were conducted in private locations. Interview notes and audio recordings were stored on secured devices, separate from any identifying information of the interviewee. References to interviewees in this report comply with 
from the Women Lawyers Association of Malawi and Women and Law in Southern Africa-Malawi ("WLSA Malawi") accompanied the Clinic team members and provided cultural support and translation services where needed.

This report draws on a combination of the Clinic fact-finding interviews and extensive desk research to highlight the reasons why the corroboration rule violates women's and girls' rights to non-discrimination, access to justice, and equality. ${ }^{15}$

\section{Definition and Background of the Corroboration Rule}

The corroboration rule has two components. First, the rule itself requires that prosecutors who are trying a sexual offence case in court provide independent evidence, from a source other than the victim's statement, which substantiates a victim's testimony. ${ }^{16}$ In nearly every other type of criminal case, the credible testimony of a single witness can be sufficient to convict an accused. ${ }^{17}$ But under the corroboration rule, a

the precise descriptor approved by the interviewee, including some instances where the interviewee chose to be referred to by a pseudonym or "anonymous" rather than any specific identifier. References also comply with the NCRSH's request that no individual's name or identifying job title be used in the report. For those interviewees who requested during the informed consent process that researchers contact them prior to use in the final report, that approval was sought and received prior to researchers' use herein.

${ }^{15}$ While the small number of interviews prohibits the researchers from drawing any conclusions regarding any statistical significance, the interviews provided extensive insight into - including first-hand accounts of - the realities on the ground.

${ }^{16}$ Mariette v. Republic [1966] 4 ALR Malawi Series 119, 134 (lines 28-30) (High Ct.) (Malawi) (defining "corroboration" as "independent testimony coming from a source other than the complainant implicating an accused which supports the testimony of the complainant").

${ }^{17}$ Corroboration of evidence is required by statute in cases involving sedition, perjury, and procuring defilement of a woman by threats or fraud or administering drugs. Criminal Procedure and Evidence Code, No. 14, § 244 (2010) (Malawi), https://malawilii.org/mw/consolidated legislation/801

[https://perma.cc/Q4KN-5JEW]; Penal Code, as amended to Act No. $24, \S \S 51,101,141$ (2012) (Malawi). Corroboration of evidence is also required for testimony given by a child who does not testify under oath. The Oaths, Affirmations and Declarations Act states in the proviso to subsection 6(1):

Provided however that where, in any proceedings against a person for any offence, any person of immature age, before the court as a witness, does not in the opinion of the court understand the nature of either an oath or an affirmation the court may receive his evidence, though not given on oath or affirmation, if, in the opinion of the court, he is possessed of sufficient intelligence to justify the reception of the evidence. 
victim's credible testimony alone is not enough to put an accused sex offender behind bars in sexual offence cases. And whereas the Criminal Procedure and Evidence Code states that "no particular number of witnesses shall in any case be required for the proof of any fact," "18 this is not so for cases involving sexual offences under the common law of Malawi. Instead, prosecutors in a rape case must always "establish in some material respect that sexual intercourse has taken place, without the woman consenting and that the defendant is the one who committed it" ${ }^{19}$-regardless of whether the victim's testimony itself is credible and proves each of these elements beyond a reasonable doubt.

In its strictest application, corroborative evidence is required for each element of a sex crime. For example, without corroborative evidence for all three elements of the crime of rape (i.e., penetration, lack of consent, and identity of the accused), ${ }^{20}$ a defendant's criminal charge will almost certainly be downgraded to a lesser criminal offence or dismissed entirely. ${ }^{21}$ In recent years, magistrates or judges who are offended by the rule's connotations about women's credibility have taken a broader view of what constitutes corroborative evidence. ${ }^{22}$ But no matter the degree to which corroborative

\footnotetext{
And in subsection 6(2): "Where evidence is received by a court in accordance with the provisions of the proviso to subsection (1), the accused shall not be liable to be convicted on such evidence unless it is corroborated by some other material evidence implicating him." Oaths, Affirmations and Declarations Act, No. 45, § 6 (1967) (Malawi), https://malawilii.org/mw/legislation/act/1967/45 [https://perma.cc/5536-66WL].

${ }^{18}$ Criminal Procedure and Evidence Code, No. 14, § 212 (2010) (Malawi),

https://malawilii.org/mw/consolidated_legislation/801 [https://perma.cc/Q4KN-5JEW] ("Subject to this Code and any other law for the time being in force, no particular number of witnesses shall in any case be required for the proof of any fact.”).
}

${ }^{19}$ Wesle v. R [1995] 1 MLR 367, 373 (High Ct.) (Malawi).

${ }^{20}$ Penal Code, as amended to Act No. 24, 132 (2012) (Malawi).

${ }^{21}$ See Mariette v. Republic [1966] 4 ALR Malawi Series 119 (High Ct.); Interview by Amy Uihlein with a Child Protection Officer at a One Stop Centre in a hospital in Malawi (Mar. 13, 2020) ("For the court to convict someone, they need to prove beyond a reasonable doubt that the incident happened and there must be other corroborating evidence for the court to convict that person.") (interview transcript confidential) (on file with the IWHRC).

${ }^{22}$ Interview by Mariame Dangnokho with a High Court Judge in Zomba, Malawi (Mar. 12, 2020) ("Corroboration can be through evidence of what they were wearing - the clothes were torn .... How familiar they are with that person and identification itself . . . Corroboration should not be looked at from the very narrow perspective, it's a broader perspective that all the evidence has to come into play. More than circumstantial evidence - that is the kind of corroboration that I'm looking for.") (interview transcript confidential) (on file with the IWHRC). 
evidence is required, the rule still binds judicial officers to require additional proof beyond a survivor's word.

A Chief Resident Magistrate illustrated the difference in treatment between a complainant of rape versus a complainant of a non-sex crime, such as robbery:

If I am robbed today [and] I represent myself before the police, "I am robbed," they will take a statement from me, they will report the items I have said have been stolen from me, and they will take my case to court. If I am raped today, they will begin to ask other questions. So, I can testify about robbery, but I cannot testify about rape. It's discriminatory. ${ }^{23}$

Second, there is an exception to the rule known as the cautionary instruction. The cautionary instruction permits (but only in very rare cases ${ }^{24}$ ) a magistrate or judge to convict a defendant in a sexual offence case without this corroborating evidence only if they warn themselves of the danger of relying on the victim's uncorroborated testimony. ${ }^{25}$ The "danger" refers to the belief that female complainants are apt to lie about being raped or sexually abused in order to protect their honor and dignity and that sex offence allegations are "easily to be made and hard to be proved, and harder to be defended by the party accused ...." ${ }^{26}$ Although sometimes referred to separately, the corroboration requirement and cautionary instruction portions of this common law rule work in tandem and are almost indistinguishable from each other in practice. The term "corroboration rule" used herein is thus an umbrella term encompassing both the requirement for corroborative evidence and/or the cautionary instruction.

\footnotetext{
${ }^{23}$ Interview by Amy Uihlein with a Chief Resident Magistrate in Malawi (Mar. 11, 2020) (interview transcript confidential) (on file with the IWHRC).

${ }^{24}$ Tinazari v. Regina [1965] 3 ALR Malawi Series 184, 192 (lines 11-24) (High Ct.) (Malawi) (stating that it should "only be in rare instances" that the uncorroborated testimony of a complainant in a sexual offence case should be accepted as truth).

${ }^{25}$ Sally Armstrong, Uprising: A New Age Is Dawning for Every Mother's Daughter 212 (2014) (citing R v. Henry \& Manning [1968] 53 Crim. App. Rep. 150, 153 (U.K.)); see also Rex v. Mussa [1942] 1923-60 ALR Malawi Series 87, 87 (line 18) (High Ct.) (Malawi) (overturning a lower magistrate court's rape conviction because the judge did not, it the court's opinion, properly warn himself of the "danger of convicting on the complaint of the prosecutrix without independent corroboration").

${ }^{26}$ HALE, supra note 9, at 634 . See infra note 113 for more details on the use of the cautionary instruction.
} 
The corroboration rule originated in old English law and was imported to Malawi during the period of colonization by the British. ${ }^{27}$ In its earliest form, the corroboration rule originated from the treatise History of the Pleas of the Crown by Sir Matthew Hale, who was Lord Chief Justice of the Court of King's Bench of England from 1671 to $1676 .{ }^{28}$ Lord Hale justified the corroboration rule by explaining that "rape is an accusation easily made and hard to be proved, and harder to be defended by the accused . ..." ${ }^{29}$ This archaic justification - and one that is rooted in the gendered stereotype that women are intrinsically unreliable, vengeful, and likely to lie about rape - pervaded English courts for nearly 350 years and is best summarized in the English cases of $R v$. Henry and $R v$. Manning:

What the judge has to do is to use clear and simple language that will without any doubt convey to the jury that in cases of alleged sexual offences it is really dangerous to convict on the evidence of the woman or girl alone. This is dangerous because human experience has shown that in these cases girls and women do sometimes tell an entirely false story which is very easy to fabricate, but extremely difficult to refute. Such stories are fabricated for all sorts of reasons, which I need not enumerate, and sometimes for no reason at all. ${ }^{30}$

To the extent that the rule is still used in modern day courts, the justification is still "based upon the discredited belief that regardless of the circumstances[,] the evidence of female complainants must be regarded as particularly suspect and particularly likely to be fabricated." ${ }^{31}$ Similarly, in Malawi courts, the justification for requiring corroboration is that "a guilty woman," much like an accomplice, is tempted to lie about her sexual encounters; and, because of this temptation, there must be an additional evidentiary

\footnotetext{
${ }^{27}$ Vikochi Jane Ndovi, The Corroboration Requirement in Sexual Offences: A Discriminatory and Unconstitutional Evidential Rule in the Malawian Law 8 (Feb. 10, 2012) (LL.M. dissertation, University of Cape Town), https://open.uct.ac.za/handle/11427/12666 [https://perma.cc/EXB5-F4QK].

${ }^{28}$ People v. Rincon-Pineda, 538 P.2d 247, 254 (Cal. 1975) (referencing HALE, supra note 9, at 633).

${ }^{29}$ HALE, supra note 9, at 634.

${ }^{30}$ Armstrong, supra note 25, at 212 (emphasis added) (citing R v. Henry \& Manning [1968] 53 Crim. App. Rep. 150, 153 (U.K.)).

${ }^{31}$ R v. Gilbert [2002] 5 LRC 606, 616 g (Privy Council 2002) (Gren.) (criticizing the corroboration rule); Jackson v. State 1998 (2) SA 267 (A) at 13 (S. Afr.) ("The cautionary rule in rape cases is based on the principle that women are naturally prone to lie and to fantasise, particularly in sexual matters and that they are naturally vengeful and spiteful.").
} 
burden imposed on her with respect to proving a fact. ${ }^{32}$ As one Chief Resident Magistrate explained, "It's really coming from the background where we are saying, 'Women don't tell the truth about such things' and when they say, 'No,' they don't really mean no."33

The corroboration rule used to exist in many parts of the world, including in other British Commonwealth nations. Today, however, Malawi stands apart from most other countries, including England (the birthplace of the rule), by retaining this legal relic as a common law rule. As part of its 2015 periodic report to the U.N. Committee on the Elimination of Discrimination Against Women ("CEDAW Committee"), the Malawi government admitted that "the evidentiary requirement in sexual violence cases remains that the corroboration rule is still required as a matter of practice." ${ }^{\prime 34}$ Conversations with some interviewees reveal a deep attachment to the rule, based on the belief that without it an innocent man can be sent to prison based on the unchecked accusations of a deceitful or vengeful woman. ${ }^{35}$ With continued sensitization and advocacy on the subject, however, the cultural tide is changing in Malawi. Legal change must follow.

\section{The Relevant Human Rights Legal Framework}

The government of Malawi is legally committed to upholding the rights of its women and girls. The Constitution of Malawi - the country's supreme legal authority - provides for "equal and effective protection" of all persons from discrimination on the basis of $\operatorname{sex}^{36}$ and further highlights women as a disadvantaged group in need of particular protections, explicitly providing for the equality and protection of women and identifying sexual violence and harassment of women and girls as a discriminatory practice that the

\footnotetext{
${ }^{32}$ Ndovi, supra note 27, at 32 (citing Rex v. Kaluwa 2 ALR Malawi Series 356).

${ }^{33}$ Interview by Amy Uihlein with a Chief Resident Magistrate, supra note 23.

${ }^{34}$ CEDAW Committee, Replies of Malawi, supra note 8, at 25.

${ }^{35}$ For example, when a religious leader was asked what he thought of abolishing the corroboration rule and he replied, "I think there's need for more discussion there, because I know that maybe the idea also is to safeguard the accused . . . so that people are not just accused falsely." Interview by Mariame Dangnokho with a religious leader in Blantyre, Malawi (Mar. 13, 2020) (interview transcript confidential) (on file with the IWHRC).

${ }^{36}$ Malawi Constitution of 1994 with Amendments through 2017, § 20(1) [hereinafter Malawi Constitution], https://www.constituteproject.org/constitution/Malawi_2017.pdf?lang=en [https://perma.cc/8MPC-SUH9] ("Discrimination of persons in any form is prohibited and all persons are, under any law, guaranteed equal and effective protection against discrimination on grounds of . . sex . . ..”).
} 
State is charged with eliminating. ${ }^{37}$ Additionally, the Constitution guarantees women and girls the right of access to justice and an effective remedy by a court of law for violations of her rights and freedoms. ${ }^{38}$ The Constitution specifies that the legislature is responsible for the enactment of laws and requires that the values inherent in the Constitution be furthered by such laws. ${ }^{39}$

These rights are also enshrined in the international human rights treaties to which Malawi is a State Party. In particular, these rights are guaranteed by the African Banjul Charter on Human and Peoples' Rights ("Banjul Charter"), ${ }^{40}$ the Protocol to the African Charter on Human and Peoples' Rights on the Rights of Women in Africa ("Maputo

\footnotetext{
${ }^{37} I d$. § 24(2) ("Any law that discriminates against women on the basis of gender or marital status shall be invalid and legislation shall be passed to eliminate customs and practices that discriminate against women, particularly practices such as ... sexual abuse, harassment and violence.”).

${ }^{38} I d$. $\S 41(2)$ ("Every person shall have the right of access to any court of law or any other tribunal with jurisdiction for final settlement of legal issues."); $i d$. $§ 41(3)$ ("Every person shall have the right to an effective remedy by a court of law or tribunal for acts violating the rights and freedoms granted to ... her by this Constitution or any other law.").

${ }^{39} I d . \S 8$.

${ }^{40}$ African [Banjul] Charter on Human and Peoples' Rights, art. 3, OAU Doc. CAB/LEG/67/3 rev. 5, 21 I.L.M. 58 (1982) (entered into force Oct. 21, 1986) (acceded to by Malawi Nov. 17, 1989) [hereinafter Banjul Charter] (stating the right to be equal before the law and to have equal protection of the law); $i d$. art. 7(1)(a) (stating the right to have one's cause heard, including the "right to an appeal to competent national organs against violations of his fundamental rights as recognized and guaranteed by conventions, laws, regulations and customs in force ..."); see List of Countries Which Have Signed, Ratified/Acceded to the African Charter on Human and Peoples' Rights (June 15, 2017), https://au.int/sites/default/files/treaties/36390-slafrican_charter_on_human_and_peoples_rights_2.pdf [https://perma.cc/VF94-UJSV].
} 
Protocol"), ${ }^{41}$ the International Covenant on Civil and Political Rights ("ICCPR"), ${ }^{42}$ and the Convention on the Elimination of All Forms of Discrimination Against Women ("CEDAW"). ${ }^{43}$

CEDAW — known as the "Bill of Rights of Women" in Malawi ${ }^{44}$ - prohibits discrimination on the basis of sex and requires that States Parties "modify or abolish existing laws, regulations, customs and practices" which constitute discrimination. ${ }^{45}$ Furthermore, CEDAW requires that States Parties, like Malawi, take all appropriate means, "including legislation, to modify or abolish existing laws ... and practices which constitute discrimination against women ...."46 Similarly, the Maputo Protocol requires that Malawi "adopt such other legislative ... . measures as may be necessary to ensure the

\footnotetext{
${ }^{41}$ Protocol to the African Charter on Human and Peoples' Rights on the Rights of Women in Africa, art. 2(1), adopted by the 2nd Ordinary Session of the Assembly of the Union, Maputo, CAB/LEG/66.6 Sept. 13, 2000, reprinted in 1 Afr. Hum. Rts. L.J. 40 (entered into force Nov. 25, 2005) (acceded to by Malawi May 20, 2005) [hereinafter Maputo Protocol] (stating that states shall "c) integrate a gender perspective in their policy decision, legislation . . . and in all spheres of life; d) take corrective and positive action in those areas where discrimination against women in law and in fact continues to exist"); id. art. 8 ("States Parties shall take all appropriate measures to ensure: a) effective access by women to judicial . . . services . . .."); id. art. 25 ("States Parties shall undertake to: a) provide for appropriate remedies to any woman whose rights or freedoms, as herein recognized, have been violated; b) ensure that such remedies are determined by competent ... authorities ....").

42 International Covenant on Civil and Political Rights, art. 2(3), U.N. Doc. A/6316 (1966), 999 U.N.T.S. 171 (entered into force Mar. 23, 1976) (acceded to by Malawi Dec. 22, 1993) [hereinafter ICCPR], https://www.ohchr.org/en/professionalinterest/pages/ccpr.aspx [https://perma.cc/H3FQ-PJ28] ("Each State Party . . . undertakes (a) To ensure that any person whose rights or freedoms as herein recognized are violated shall have an effective remedy ...."); id. art. 3 (stating the equal right of men and women in the enjoyment of the rights in the Covenant); $i d$. art. 14(1) ("All persons shall be equal before the courts and tribunals.").

${ }^{43}$ Convention on the Elimination of All Forms of Discrimination Against Women, art. 2(a), U.N. Doc. A/34/36 (1979), 1249 U.N.T.S. 13 (entered into force Sept. 3, 1981) (acceded to by Malawi Mar. 12, 1987) [hereinafter CEDAW], https://www.ohchr.org/EN/ProfessionalInterest/Pages/CEDAW.aspx [https://perma.cc/MRF3-VZYN] (stating that states parties undertake "[t]o embody the principle of equality of men and women ... and to ensure, through law and other appropriate means, the practical realization of this principle ..."); $i d$. art. 15(2) ("States Parties shall ... treat [women and men] equally in all stages of procedure in courts and tribunals.").

${ }^{44}$ Malawi L. Comm’n, Report No. 23: Report on the Gender Equality Act 10 (Feb. 23, 2011), https://tbinternet.ohchr.org/Treaties/CEDAW/Shared\%20Documents/MWI/INT_CEDAW_ADR_MWI_1951 8_E.pdf [https://perma.cc/A9J2-4G7V].

${ }^{45}$ CEDAW, supra note 43 , art. 2(f).

${ }^{46} I d$.
} 
prevention, punishment and eradication of all forms of violence against women . ..."47 and requires that Malawi "integrate a gender perspective" in its policy decisions and legislation and "take corrective and positive action in those areas where discrimination against women in law and in fact continues to exist." ${ }^{48}$

The CEDAW Committee has stressed that "all judicial bodies are required to ... . ensur[e] that all legal procedures in cases involving allegations of gender-based violence against women are impartial, fair and unaffected by gender stereotypes. ${ }^{\circ 9}$ More specifically, the CEDAW Committee has called on Malawi to take proactive action to end damaging stereotyping against women - including explicitly calling for an end to the corroboration rule.$^{50}$ In its General Recommendation No. 33 on Women's Access to Justice, the CEDAW Committee established that "corroboration rules that discriminate against women ... by requiring them to discharge a higher burden of proof than men in order to establish an offence or to seek a remedy" are "discriminatory barriers to access to justice." ${ }^{51}$

The CEDAW Committee also stated that harmful stereotypes, such as the one underpinning the corroboration rule, "impede women's access to justice ... and may have a particularly negative impact on women victims and survivors of violence." ${ }^{, 52}$ More specifically, the Committee has declared that the "application of preconceived and stereotypical notions of . . the standard of proof required to substantiate [gender based violence] can affect women's rights to ... [an] effective remedy." ${ }^{53}$ Likewise, the U.N. Declaration on the Elimination of Violence against Women proclaims that "States should

\footnotetext{
${ }^{47}$ Maputo Protocol, supra note 41, art. 4(2)(b).

${ }^{48} I d$. art. 2(1)(c)-(d).

${ }^{49}$ CEDAW Committee, General Recommendation No. 35, Gender-Based Violence Against Women (67th Sess., 2017), ๆ 26(c), U.N. Doc. CEDAW/C/GC/35 (July 26, 2017) [hereinafter CEDAW GR 35].

${ }^{50}$ CEDAW Committee, General Recommendation No. 33, Women's Access to Justice (61st Sess., 2015), 9 26, U.N. Doc. CEDAW/C/GC/33 (Aug. 3, 2015) [hereinafter CEDAW GR 33].

${ }^{51} I d$. $125(\mathrm{a})$.

${ }^{52} I d$. 26 ("Stereotyping also affects the credibility given to women's voices, arguments and testimony as parties and witnesses. Such stereotyping can cause judges to misinterpret or misapply laws. This has farreaching consequences, for example, in criminal law, where it results in perpetrators not being held legally accountable for violations of women's rights, thereby upholding a culture of impunity.").

${ }^{53} I d$.
} 
condemn violence against women," ${ }^{54}$ and "women who are subjected to violence should be provided with access to the mechanisms of justice and ... to just and effective remedies for the harm that they have suffered ... as provided for by national legislation." 55

Furthermore, the African Commission on Human and Peoples' Rights has determined that the right to an effective remedy for victims of sex crimes requires that "the prosecution of the perpetrators [is] carried out ... in a manner that will lead to the ... sentencing of the perpetrators. ${ }^{~} 56$ The African Commission has expressed concern that sexual violence is widespread in Africa and has expressed "regret[] that the perpetrators of this violence continue to enjoy almost complete impunity." Guidelines on Combating Sexual Violence and Its Consequences in Africa, developed by the African Commission on Human and Peoples' Rights, proclaim that preventing "discriminat[ion] against victims of sexual violence" in their access to justice requires that "the statement of the victim can be sufficient proof of an act of sexual violence in the absence of any other corroborating evidence." ${ }^{58}$ These guidelines further instruct that countries must ensure that the "absence of evidence corroborating the victim's testimony does not prevent judicial prosecution as well as the judgment of the perpetrator . ..."59

In its 2015 Concluding Observations on Malawi's seventh periodic report, the CEDAW Committee urged Malawi specifically to "ensure, in law and in practice, that evidentiary requirements in criminal cases relating to sexual offences do not lead to

\footnotetext{
${ }^{54}$ G.A. Res. 48/104, art. 4, Declaration on the Elimination of Violence Against Women (Dec. 20, 1993), https://www.un.org/en/genocideprevention/documents/atrocitycrimes/Doc.21_declaration\%20elimination\%20vaw.pdf [https://perma.cc/9FNU-TXRL].

${ }^{55} I d$. art. 4(d).

56 African Comm'n on Hum. And Peoples' Rts., Guidelines on Combating Sexual Violence and Its CONSEQUENCES IN AFRICA 1, 18 (2017), www.achpr.org/legalinstruments/detail?id=4 [https://perma.cc/V6WG-U4MT] [hereinafter ACHPR Guidelines on COMBATing SEXUAL Violence].

${ }^{57} I d$. at 9.

${ }^{58} I d$. at 34 .

${ }^{59} \mathrm{Id}$. at 45 .
} 
impunity for the perpetrators. ${ }^{960}$ The Committee further cautioned States Parties that the perpetuation of gender stereotypes not only "affects the credibility given to women's voices, arguments and testimonies" but can also "cause judges to misinterpret or misapply laws"- perpetuating impunity for offenders. ${ }^{61}$

Thus, the human rights legal framework makes it clear that Malawian women and girls are legally entitled to be free from the discriminatory treatment caused by the corroboration rule and to see their sexual abusers be brought to justice. Furthermore, Malawi is bound to undertake all appropriate measures, including by adopting or amending legislation, to give effect to these rights. ${ }^{62}$ An evidentiary requirement that denies women and girls access to justice and discriminates against them on the basis of sex directly violates the Constitution and international laws, and has no place in Malawi's criminal justice system.

Abolishing the archaic corroboration rule would also align Malawi with many jurisdictions in the modern world with respect to this aspect of criminal procedure.

${ }^{60}$ CEDAW Committee, Concluding Observations: Malawi (62nd Sess., 2015), $\uparrow$ 23(b), U.N. Doc. CEDAW/C/MWI/CO/7 (Nov. 24, 2015). The Committee on the Rights of the Child has also urged Malawi to "revise the requirement for corroboration in sexual offences and modify it to ensure that child victims are not denied justice." Comm. on the Rights of the Child, Concluding Observations on the Combined Third to Fifth Periodic Reports of Malawi (74th Sess., 2017), ๆ 23(f), U.N. Doc. CRC/C/MWI/CO/3-5 (Mar. 6, 2017).

${ }^{61} I d$.

${ }^{62}$ CEDAW, supra note 43, art. 2(f)-(g) ("States Parties condemn discrimination against women in all its forms, agree to pursue by all appropriate means and without delay a policy of eliminating discrimination against women and, to this end, undertake: to take all appropriate means, including legislation, to modify or abolish existing laws ... which constitute discrimination against women; [and] to repeal all national penal provisions which constitute discrimination against women ...."); Maputo Protocol, supra note 41, art. 4(2)(b) ("States Parties shall take appropriate and effective measures to . . adopt such other legislative ... measures as may be necessary to ensure the prevention, punishment and eradication of all forms of violence against women ...."). 
Countries that have abolished the rule or have denounced its use in courts include
Australia,${ }^{63}$ Bangladesh, ${ }^{64}$ Canada,${ }^{65}$ Eswatini,${ }^{66}$ Fiji,${ }^{67}$ Grenada,${ }^{68}$ India,${ }^{69}$ Kenyaa,${ }^{70}$

\begin{abstract}
${ }^{63} R v$ Longman (1989), 168 CLR 79 (Austl.) (stating that the corroboration rule "casts indiscriminately on the evidence of all alleged victims of sexual offences, the vast majority of whom are women, and the corresponding protection which the giving of a warning confers on an accused in all cases of sexual offences ... [is] unwarranted and the protection [is] unjust"). Moreover, "[i]t is not necessary that evidence on which a party relies be corroborated.” Evidence Act 1995 (Cth) s 164(1) (Austl.) (as amended to 2016),

www.legislation.gov.au/Details/C2016C00605/Html/Text [https://perma.cc/CS33-NVRJ]. Despite "any rule, whether of law or practice, to the contrary, but subject to the other provisions of this Act, if there is a jury, it is not necessary that the judge: (a) warn the jury that it is dangerous to act on uncorroborated evidence to give a warning to the same or similar effect; or (b) give a direction relating to the absence of corroboration." Id. $\mathrm{s}$ $164(3)$.
\end{abstract}

${ }^{64}$ Christine Chinkin, Addressing Violence Against Women in the Commonwealth Within States' Obligations Under International Law, 40 Commonwealth L. Bull. 471, 492 (2014) (citing Al Amin v. State, 19 Bangl. High Ct. Div. 307 (1999) (finding that the "testimony of a victim of sexual assault is vital, and ... the court should find no difficulty in convicting an accused on her testimony alone if it inspires confidence and is found to be reliable.")).

${ }^{65}$ Canada Criminal Code, R.S.C. 1985 , c. C-46 § 274, laws-lois.justice.gc.ca/PDF/C-46.pdf

[https://perma.cc/N6N2-G49N] ("If an accused is charged with a[] [sexual] offence ... no corroboration is required for a conviction and the judge shall not instruct the jury that it is unsafe to find the accused guilty in the absence of corroboration.").

${ }^{66}$ Sexual Offences and Domestic Violence Act, No.15, § 49 (2018) (Eswatini), $\mathrm{http} / / / \mathrm{www}$. ilo.org/dyn/natlex/natlex4.detail?p_lang=en\&p_isn=108709\&p_country=SWZ

[https://perma.cc/8Z6S-CTK2] ("Notwithstanding the provisions of the common law, any other law or rule of practice, a Court shall not treat the evidence of a witness in criminal proceedings before that Court with caution and shall not call for corroboration of evidence solely on account of the fact that the witness is (a) the complainant of a sexual offence; or (b) a child.")

${ }^{67}$ Balelala v. S [C.A] 20045 LRC 5, 365, 381 (Fiji) (holding that the corroboration rule is "counterproductive, confusing, and both discriminatory and demeaning of women," represents "an outmoded and fundamentally flawed view," and therefore must be invalidated"); Criminal Procedure Decree 2009, REPUBlic of FiJ IsLANDS GovernMENT GAZETTE, Vol. 10, No. 94, 935, 975 (2009), ilo.org/dyn/natlex/natlex4.detail?p_lang=en\&p_isn=86235\&p_country=FJI\&p_count=296 [https://perma.cc/UDJ5-USUC] ("Where any person is tried for an offence of a sexual nature, no corroboration of the complainant's evidence shall be necessary for that person to be convicted; and in any such case the judge or magistrate shall not be required to give any warning to the assessors relating to the absence of corroboration.").

${ }^{68}$ R v. Gilbert [2002] 5 LRC 606 (Privy Council 2002) (Gren.), at 616 g (stating that the "discredited belief" about "female complainants" is "not conducive to the fairness of the trial nor the safety of the verdict"). 
Lesotho, ${ }^{71}$ Namibia, ${ }^{72}$ Seychelles, ${ }^{73}$ Uganda,${ }^{74}$ and all fifty of the United States and the District of Columbia. ${ }^{75}$ England - the birthplace of the rule - abolished the rule

\footnotetext{
${ }^{69}$ Maharashtra v. Jain, 1990 SCR (1) 115 (India) (stating that the corroboration rule is "an insult to womanhood" and it "would be adding insult to injury to tell a woman that her story of woe will not be believed unless it is corroborated").

${ }^{70}$ Mukungu v. Republic (2002) 2 E.A. 482 (C.A.K.) (Kenya) (noting that "the same caution is not required of the evidence of women and girls in other offences," and stating that "the requirement for corroboration in sexual offences affecting adult women and girls is unconstitutional ... [and] cannot be properly justified"); see also Evidence Act of 1963 (as amended to 2014) Cap. $80 \S 124$ (Kenya) (stating that notwithstanding the provisions of the Oaths and Statutory Declarations Act that pertain to evidence given by young children, "the accused shall not be liable to be convicted on such evidence unless it is corroborated by other material evidence in support thereof implicating him: Provided that where in a criminal case involving a sexual offence the only evidence is that of the alleged victim of the offence, the court shall receive the evidence of the alleged victim and proceed to convict the accused person if . . the court is satisfied that the alleged victim is telling the truth.”).
}

${ }^{71}$ Sexual Offences Act, (2003) §18, Vol. XLVIII No. 29, Government GaZetTe ExtRaORdinary (Lesotho) ("No court shall treat the evidence of any complainant in criminal proceedings at which an accused is charged with an offence of a sexual nature with special caution on the basis that the accused is charged with that offence."),

https://lesotholii.org/ls/legislation/act/2003/3/lesotho_sexual_offences_act_2003_pdf_14292.pdf [https://perma.cc/GTX3-C4TU].

${ }^{72}$ State v. D [1992] LRC (Crim) 253 (High Ct.) 257 h (Namib.) (“[T]he so-called cautionary rule has no other purpose than to discriminate against women complainants. This rule thus probably also is contrary to ... the Namibian Constitution which provides for equality of all persons before the law regardless of sex."); Combating of Rape Act, (2000) §5, GovernMENT GAZETTE OF THE RePUBLic OF NAMiBIA ("No court shall treat the evidence of any complainant in criminal proceedings at which an accused is charged with an offence of a sexual or indecent nature with special caution because the accused is charged with any such offence."), https://laws.parliament.na/cms_documents/gg-2326-80d4e0091e.pdf [https://perma.cc/E4FQ-ZU3U].

${ }^{73}$ Lucas v. Republic [2012] 3 LRC 155 (C.A.) 166 b (Sey.) (concluding that "to say that every complainant in a sexual offence case was less worthy of belief than any other witness was an affront to their dignity" and violated the constitutionally protected right to equal protection of the law without discrimination).

${ }^{74}$ Ntamnala v. Uganda [2018] Cr. App. No. 34 of 2015 (Sup. Ct.) 5 (Uganda) (Tibatemwa-Ekirikubinza, J., Concurring) (invalidating corroboration rule and noting that "the requirement for corroboration of evidence in sexual offences is discriminatory against women and ... therefore ... violates Uganda's Constitutional provisions on equality before the law”).

${ }^{75}$ Richard Bialczak \& Dorothy Wong, Evidentiary Matters in Sexual Offence Cases, 4 Geo. J. Gender \& L. 525, 527 (2002); see also Richard Klein, An Analysis of Thirty-Five Years of Rape Reform: A Frustrating Search for Fundamental Fairness, 41 AKRON L. Rev. 981, 986 (2008) ("There is no state which, as of 2001, still generally requires corroboration."). 
legislatively in $1994{ }^{76}$ and the English Court of Appeal upheld the statutory ban against the corroboration rule in cases involving sexual offences - doubling down on the eradication of an antiquated and discriminatory practice that originated in its own jurisprudence. ${ }^{77}$ South Africa also passed the Criminal Law (Sexual Offences and Related Matters) Amendment Act in 2007, ${ }^{78}$ following a decision by the Supreme Court of Appeal that criticized the continued use of the corroboration rule and favoring the modern approach used by England. ${ }^{79}$

At one point in time, many, if not most, of these countries believed that the corroboration rule was needed to uphold a defendant's right to a fair trial and, further, that evidence of forcible sex should be easy to obtain. ${ }^{80}$ That is, the rule did not impose a high barrier for survivors, and it prevented innocent men from being thrown in prison based on a false accusation. ${ }^{81}$ These beliefs still pervade Malawian society and they are obstacles to abolishing the corroboration rule. ${ }^{82}$ Some interviewees saw abolition of the rule not as a way to equalize the scales, but as a "feminist position," indeed, an "extreme

\footnotetext{
${ }^{76}$ Criminal Justice and Public Order Act 1994, c. $33 \S 33$ (U.K.), http://www.legislation.gov.uk/ukpga/1994/33/section/33 [https://perma.cc/V6U7-2WWK] (repealing the corroboration requirement provisions of the Sexual Offences Act 1956).

${ }^{77}$ R v. Makanjuola and R v. Easton [1995] 3 All ER 730, 731 (Eng.) (upholding the statutory ban against the corroboration rule in sexual cases in England shortly after the ban was enacted).

${ }^{78}$ Criminal Law (Sexual Offences and Related Matters) Amendment, GN 1224, GG $30599 \S 60$ (14 Dec. 2007) ("Notwithstanding any other law, a court may not treat the evidence of a complainant in criminal proceedings involving the alleged commission of a sexual offence pending before that court, with caution, on account of the nature of the offence.") (S. Afr.).

${ }^{79}$ Jackson v. State 1998 (2) SA 267 (A) at 18 (S. Afr.) (noting that the rule "unjustly stereotypes complainants in sexual assault cases (overwhelmingly women) as particularly unreliable.").

${ }^{80}$ For example, a professor of law in Scotland opined, "Clearly if the corroboration requirement is retained, some victims of crime will be denied justice. But if it is abolished, it is likely that more accused will be unjustly convicted." Donald Nicolson, Scrapping Corroboration Rule Will Undermine Scottish Justice, CONVERSATION (Mar. 4, 2014), https://theconversation.com/scrapping-corroboration-rule-will-underminescottish-justice-23859 [https://perma.cc/XSR3-UPE8].

${ }^{81} \mathrm{Id}$.

${ }^{82}$ See supra note 35 .
} 
position." ${ }^{83}$ And, as one interviewee noted, the rule should perhaps be retained because "the law should be fair on both sides so that no one takes advantage of the other." 84

However, the legal protections that a defendant had in seventeenth-century England (and in other jurisdictions to which the rule was exported) pales in comparison to the robust suite of constitutional legal rights for defendants around the world today, even in Malawi. ${ }^{85}$ These rights include the presumption of innocence, the right to a public trial before an independent and impartial court of law, the right to remain silent and to not have his statements used against him, the right to challenge evidence, the right to be represented by a legal practitioner (where it is required in the interests of justice), and the right to an appeal or review by a higher court, among other things. ${ }^{86}$ The antiquated and unsupported belief that accusations of sex crimes are "harder to defend against by the accused" is misplaced in the modern criminal justice system.

These legal changes, together with empirical evidence showing that female survivors of sexual violence are no more apt to lie about being raped than about any other type of crime, forced these countries to examine the corroboration rule in a critical light. ${ }^{87}$ As

\footnotetext{
${ }^{83}$ Interview by Mariame Dangnokho with a State Advocate in Lilongwe, Malawi (Mar. 11, 2020) ("The corroboration [rule] is important in the way that you know when you are sending someone to prison it's a very, very serious offence. You're curtailing the constitutional rights of that individual, that suspect. So, the court has to balance [that]. The court has to satisfy itself that indeed X committed a criminal offence ... that he really did it.") (interview transcript confidential) (on file with the IWHRC).

${ }^{84}$ Interview by Amy Uihlein with a senior manager, Youth Net and Counselling (YONECO), in Zomba, Malawi (Mar. 12, 2020) (interview transcript confidential) (on file with the IWHRC).

${ }^{85}$ See People v. Rincon-Pineda, 538 P.2d 247, 256-57 (Cal. 1975) (discussing the writings of Sir Matthew Hale, Lord Chief Justice of the Court of King's Bench from 1671 to 1676, and how his belief in the perilous position of the defendant charged with a sex crime was informed by the basic lack of protection afforded defendants in seventeenth-century England). Under old English common law, the burden of proof was not beyond a reasonable doubt, and the defendant was not entitled to the assistance of counsel. Id. He was not presumed innocent and could not compel witnesses to appear in his defense. Id. Each of these rights that were unavailable to defendants in seventeenth-century England are guaranteed to defendants of rape and defilement by the Constitution of Malawi. Malawi Constitution, supra note 36, § 42(2)(f); see also Attorney General v. Malawi Congress Party \& Others [1997] Civ. App. No. 22 of 1996 (MSCA) ("[T] he person so accused of crime shall be presumed innocent until proved guilty.”)

${ }^{86}$ Malawi Constitution, supra note 36, $\S ~ 42(2)(a)$, (f)(i), (f)(iii)-(v), (f)(viii).

${ }^{87}$ Jackson v. State 1998 (2) SA 267 (A) at 13-14 (S. Afr.) (stating that "empirical research has been done refut[ing] the notion that women lie more easily or frequently than men, or that they are intrinsically unreliable witnesses") (citing Dianne Hubbard, A Critical Discussion of the Law of Rape in Namibia, in
} 
such, many of these countries have jettisoned the corroboration rule based on a determination that the assumption that women lie is rooted in a gendered stereotype, is discrimination on the basis of sex, and has no rational purpose other than to discriminate against women. Malawi should do the same.

\section{The Corroboration Rule Renders Justice Elusive for Survivors of Sex Crimes}

"Access to justice is elusive for many survivors of sexual violence."

The right of access to justice is guaranteed by the Malawi Constitution as well as the international treaties to which Malawi is a State Party. The Malawi Constitution guarantees to women and girls the right to an effective remedy in a court of law. ${ }^{89}$ This right is also enshrined in the ICCPR $,{ }^{90} \mathrm{CEDAW},{ }^{91}$ the Maputo Protocol, ${ }^{92}$ and the Banjul Charter. ${ }^{93}$ In addition, the U.N. Declaration on the Elimination of Violence against

Putting Women on the Agenda 156 (Susan Bazilli ed., 1991) ("A US study found that the incidence of false reports for rape is exactly the same as that for other felonies_about two per cent.") (quoting JULIE A. Allison \& LaWrence Wrightsman, Rape: The Misunderstood Crime 205 (1993) (noting that the study was done by the New York Sex Crimes Analysis Unit)). There is no evidence to suggest these statistics have changed significantly over the last twenty years.

${ }^{88}$ UNICEF ACCESS TO JUSTICE REPORT, supra note 6, at 7.

${ }^{89}$ Malawi Constitution, supra note $36, \S 41(3)$.

${ }^{90}$ ICCPR, supra note 42, art. 2(3) ("Each State Party . . . undertakes (a) To ensure that any person whose rights or freedoms as herein recognized are violated shall have an effective remedy ....”).

${ }^{91}$ CEDAW, supra note 43, art. 15(2) ("States Parties shall . . . treat [women and men] equally in all stages of procedure in courts and tribunals."); CEDAW GR 35, supra note 49, ๆ 29(b) ("The Committee recommends that States parties . . . ensure that all legal systems . . . protect victims/survivors of gender-based violence against women and ensure that they have access to justice and to an effective remedy . ...."); CEDAW GR 33, supra note 50, ๆ $18(\mathrm{e}), 26,29$.

${ }^{92}$ Maputo Protocol, supra note 41, art. 8 ("States Parties shall take all appropriate measures to ensure: a) effective access by women to judicial ... services . ..."); id. art. 25 ("States Parties shall undertake to: a) provide for appropriate remedies to any woman whose rights or freedoms, as herein recognized, have been violated; b) ensure that such remedies are determined by competent . . . authorities . ...").

${ }^{93}$ Banjul Charter, supra note 40, art. 7(1) ("Every individual shall have the right to have his cause heard. This comprises: (a) the right to an appeal to competent national organs against acts of violating his fundamental rights as recognized and guaranteed by conventions, laws, regulations and customs in force."). 
Women proclaims that "States should condemn violence against women,"94 and "women who are subjected to violence should be provided with access to the mechanisms of justice and ... to just and effective remedies for the harm that they have suffered ...."95

The corroboration rule stands as a concrete roadblock to accessing justice for victims of sex crimes in violation of domestic and international law. The corroboration rule's demands on police, prosecutors, magistrates, and judges in effect operate to exempt sexual abusers from criminal punishment. In the words of a lawyer at the Ministry of Justice and Constitutional Affairs, "It's tragic. You have a real victim who cannot get a remedy before a court because they're not able to corroborate their statements." ${ }^{\prime 96}$

\section{A. The Corroboration Rule Obstructs the Investigation, Prosecution, and Conviction of Individuals in Sexual Offence Cases and Denies Victims an Effective Remedy}

The requirement that a sexual offence conviction be supported by independent evidence corroborating a survivor's testimony - whether or not that testimony was made under oath, was credible, or proves beyond a reasonable doubt that the sex crime took place - leads to significant case attrition throughout the criminal justice process. A 2019 UNICEF Access to Justice report on sexual violence in Malawi, which analyzed the results of 138 reports of rape, statutory rape, and other sexual offences, found that nearly twenty-five percent of incidents reported to police failed to result in an arrest because, among other things, there was no corroborative evidence, such as a medical report. ${ }^{97}$ Furthermore, sixteen percent of cases that eventually made it to court resulted in the outright acquittal of the perpetrator due to a lack of corroborative evidence. ${ }^{98}$ The UNICEF report determined that "[a]cquittals at magistrate court for sexual offences due to lack of corroborative evidence amount to gender bias, discrimination and oppression of

\footnotetext{
${ }^{94}$ G.A. Res. 48/104, supra note 54, art. 4.

${ }^{95} I d$. art. 4(d).

${ }^{96}$ Interview by Amy Uihlein with a lawyer, Ministry of Justice and Constitutional Affairs, in Lilongwe, Malawi (Mar. 10, 2020) (interview transcript confidential) (on file with the IWHRC).

${ }^{97}$ UNICEF ACCESS to JuSTICE RePORT, supra note 6, at 32.

${ }^{98} I d$. at 21 .
} 
the survivor ... and the standard hence unfavourabl[y] impact[s] on women's and children's access to justice." 99

The CEDAW Committee, in its General Recommendation No. 33 on Women's Access to Justice, recognized that gender stereotypes, such as the one that undergirds the corroboration rule, have the potential to infiltrate all stages of the criminal justice system:

Judges, magistrates and adjudicators are not the only actors in the justice system who apply, reinforce and perpetuate stereotypes. Prosecutors, law enforcement officials and other actors often allow stereotypes to influence investigations and trials, especially in cases of gender-based violence, with stereotypes undermining the claims of the victim/survivor and simultaneously supporting the defense advanced by the alleged perpetrator. Stereotyping can, therefore, permeate both the investigation and trial phases and shape the final judgement. ${ }^{100}$

Indeed, the corroboration rule, though used as a rule of evidence in the courtroom, has far reaching impacts and consequences.

\section{Investigation by Police}

With regard to the investigation stage, interviewees recounted incidents where police abdicated their responsibility to investigate reports of sexual offences because there was no immediate corroborative evidence. ${ }^{101}$ "[The police] ask for evidence that comes from

\footnotetext{
${ }^{99} I d$. at 30 .

${ }^{100}$ CEDAW GR 33, supra note 50, ๆ 27.

101 We have cases whereby a child was raped maybe three months ago. When they go to the police, they are told there is no evidence despite producing a medical report. They will be told there is no evidence. "You know, your daughter wanted to have sex." Now, you think of a child who is 5 years old, but police say she wanted to have [sex]. It is not fair because I don't think I can just wake up today and say, "Somebody has raped me." Their responsibility is to find out how and to support me based on the issue I've presented to them. However, it's not the case.
}

Interview by Amy Uihlein with a manager, YONECO, in Zomba, Malawi (Mar. 12, 2020)

(interview transcript confidential) (on file with the IWHRC). 
the doctor's assessments," 102 said a psychosocial counselor of victims of sexual assault in Malawi. "That's the first hard evidence that they want to see." ${ }^{103}$ A Chief Resident Magistrate confirmed this understanding: "I know the police," 104 she said. "The background that they have is you need corroboration." ${ }^{105}$ In the absence of such evidence, like a medical report, "you'll find that such cases will not even see the court. At that stage, they'll say, 'we have no evidence, we can't take your matter to court."' ${ }^{106}$ For example, the UNICEF Access to Justice report showed that, in thirty-six out of 138 incidents of alleged sexual violence, police declined to arrest a known perpetrator for reasons such as "no evidence, i.e. medical report showing that nothing sexual happened" and "medical tests did not show defilement of the girl."107

An official with WLSA-Malawi, a research and advocacy group on gender-related issues, recalled a case where a woman was ambushed by men on her way home from work one night and went to the police two days later to report the incident. "However, when she went there," the official said, "they told her that she needed to go to the hospital first to get a medical report .... She wasn't able to get that medical report and I remember one of the biggest [reasons why they] were unable to get the case prosecuted was the absence of the medical report. Because she couldn't get the medical report, she couldn't get the police report." ${ }^{, 108}$ In the absence of readily available corroborating evidence, investigations are abandoned before they truly begin.

\section{Prosecution by Lawyers}

The corroboration rule also stymies the work of prosecutors who know that they must bring a strong case with corroborating evidence if they have any chance of succeeding at trial. "An acquittal embarrasses a prosecutor and you look as if you don't know your

\footnotetext{
102 Interview by Mariame Dangnokho with a psychosocial counselor of victims of sexual assault in Lilongwe, Malawi (Mar. 9, 2020) (interview transcript confidential) (on file with the IWHRC).

${ }^{103} I d$.

${ }^{104}$ Interview by Amy Uihlein with a Chief Resident Magistrate, supra note 23.

${ }^{105} \mathrm{Id}$.

${ }^{106} I d$.

${ }^{107}$ UNICEF ACCESS to JustiCE REPORT, supra note 6, at 32.

108 Interview by Mariame Dangnokho with an official, Women and Law in Southern Africa-Malawi, in Lilongwe, Malawi (Mar. 8, 2020) (interview transcript confidential) (on file with the IWHRC).
} 
job," 109 said a state prosecutor. "[A]nd thus in the absence of corroboration many prosecutors just drop the case." 110 This attitude conflicts with the Principles and Guidelines on the Right to a Fair Trial and Legal Assistance in Africa issued by the African Commission on Human and Peoples' Rights. These principles and guidelines explicitly call on prosecutors to "respect and protect dignity and uphold human rights" and to "carry out their functions impartially and avoid all ... sexual, gender or any other kind of discrimination." 112

\section{Adjudication by Judges}

Judicial precedent shows an insistence on corroborative evidence in all sexual offence court cases, ${ }^{113}$ without which a ruling can result in dismissal of a case or an acquittal, ${ }^{114}$ reversal of a conviction on appeal, ${ }^{115}$ or reversal with a downgrade to a lesser

\footnotetext{
${ }^{109}$ Malunga, supra note 5, at 54 (quoting a state prosecutor).

${ }^{110} I d$.
}

111 African Commission on Human and Peoples' Rights, Principles and Guidelines on the Rights to a Fair Trial and Legal Assistance in Africa 9 F(h) (2003), https://www.achpr.org/legalinstruments/detail?id=38 [https://perma.cc/5UN7-GLCA].

${ }^{112} I d$. 甲 F(i)(i).

${ }^{113}$ Ndovi, supra note 27, at 6-7. In cases that lack corroborative evidence, a magistrate may convict on the uncorroborated testimony of a witness so long as she warns or instructs herself of the dangers of relying on such testimony (i.e., that an allegation is easily made and hard to disprove). Id. This cautionary instruction is also called the "cautionary warning," and the High Court has held that a conviction founded on such a warning in the absence of corroboration should be made only under exceptional circumstances. $I d$. at 10 (citing Tinazari v. Regina [1965] 3 ALR Malawi Series 184 (High Ct.) (Malawi)).

${ }^{114}$ Interview by Allison Carlon with an executive, Women Lawyers Association of Malawi, in Lilongwe, Malawi (Mar. 8, 2020) ("There was a case of gang rape that was thrown out for lack of corroboration. They say they need a medical report, they need to be able to have a reliable witness, need to prove that consent wasn't there. I mean, with a case of the rape, she could identify the persons that raped her, and that should have sufficed. If she said she recognized them and she was able to point them out, that should suffice. But it did not.") (interview transcript confidential) (on file with the IWHRC).

${ }^{115}$ See Republic v. Malenga [2007] Crim. App. No. 326 of 2006 (High Ct.) (Malawi) (overturning Senior Resident Magistrate's conviction of rape based on an appeal by the defendant that the conviction was based on uncorroborated testimony). 
offence on appeal ${ }^{116}$-none of which are effective remedies. Referring again to the UNICEF Access to Justice report, of the sixty-one cases that actually made it into the court system, ten of those cases resulted in acquittals for a lack of corroborative evidence. ${ }^{17}$

Bernadette Malunga, a former magistrate and a member of the Women Lawyers Association of Malawi, wrote in her thesis on the corroboration rule that "[c]onviction on uncorroborated evidence without warning by the trial court is fatal to the case when it goes for review or on appeal. An appellate court may overturn the conviction even if it is convinced that an accused person was guilty." 118 As a result, the rule serves as a significant barrier to the investigation, prosecution and conviction of perpetrators of sexual offences - contravening the Malawi Constitution and international human rights guarantees and resulting in the denial of an effective remedy for survivors.

\section{B. The Assumption that Corroborative Evidence Is Present and Available Belies the Lived Experiences of Survivors, and Imposes an Unrealistic Burden on Complainants of Sexual Violence}

"Sometimes, it is just the evidence of the girl, screaming for help." 119

The continued use of the corroboration rule is based, in part, on the false assumptions that independent evidence- for example, in the form of an eyewitness or a telling medical report-is usually present and available in the aftermath of a sex crime, and that, without this evidence, a female survivor might be lying. ${ }^{120}$ "I don't think it is difficult to

\footnotetext{
116 See Mariette v. Republic [1966] 4 ALR Malawi Series 119, 139 (lines 21-23) (High Ct.) (Malawi) (overturning a rape conviction and substituting a conviction for attempted rape because there was no corroborative evidence to show penetration by the penis had occurred).

${ }^{117}$ UNICEF ACCESS to JuSTICE RePORT, supra note 6, at 21.

${ }^{118}$ Malunga, supra note 5, at 17 (emphasis added); see also Rex v. Mussa [1942] 1923-60 ALR Malawi Series 87, 87 (line 18) (High Ct.) (Malawi) (overturning a lower magistrate court's rape conviction because the judge did not, in the court's opinion, properly warn himself of the "danger of convicting on the complaint of the prosecutrix without independent corroboration").

${ }^{119}$ Interview by Darya Vakulenko with a women's rights lawyer in Lilongwe, Malawi (Mar. 9, 2020) (interview transcript confidential) (on file with the IWHRC).

${ }^{120}$ See Malunga, supra note 5, at 61-62.
} 
get corroborative evidence," ${ }^{\prime 21}$ said a supreme court judge about the likelihood of having physical evidence of lack of consent. "[T]orn clothes, bruises, all these act[] as corroboration of lack of consent. I think it's easy to get it. Maybe [I] am just being naïve because I have always thought that if a lady is refusing there will be evidence to show the same." ${ }^{122}$ However, the stereotype that survivors will always respond to unwanted sex with physical resistance, an immediate report to the police, or other "rigid standards about what [judges] consider to be appropriate behavior for women . . . penalize[s] those who do not conform to those stereotypes," 123 and ignores the fact that rape often occurs under the threat of physical harm, undue influence, fear, and coercion. ${ }^{124}$

Interviews with affected women and various stakeholders in Malawi illustrate the significant difficulties that survivors have in securing and retaining the kinds of evidence that would be needed by prosecutors to succeed at trial. For cases of statutory rape, incest, and sex with minors under one's care or protection, corroborative evidence would be needed to prove (1) the identity of the assailant and (2) that there was penile penetration into a vagina. ${ }^{125}$ For cases of rape, the additional element of lack of consent would also need corroborative evidence. ${ }^{126}$ Each of these evidentiary requirements presents unique and substantial challenges for survivors seeking justice under the law.

${ }^{121} I d$. at 38 (quoting a supreme court judge).

${ }^{122} \mathrm{Id}$.

${ }^{123}$ CEDAW GR 33, supra note 50, ๆ 26.

${ }^{124}$ See Malunga, supra note 5, at 38 (quoting a state prosecutor: "The question of lack of consent also gives challenges in securing corroborative evidence to it because the offence happen[s] in secret and most of the times the court looks at scratches or signs of struggle which might not be there in some cases due to fear or undue influence which may cause the victim not to struggle and hence in such cases there will be no scratches or bruises to show lack of consent.").

${ }^{125}$ See the elements for these offences in the Penal Code, as amended to Act No. 24, §§ 138, 157-58, 159A (2012) (Malawi).

${ }^{126}$ Id. $\S 132$. 


\section{Identity of the Assailant}

Corroborating evidence proving the identity of an assailant can be difficult to obtain. ${ }^{127}$ "It would be highly difficult ... to have a witness - somebody who will testify [as] to what happened to you," 128 said a legal intern of a law firm in Lilongwe. There is "close to zero percent [chance] of that happening," ${ }^{29}$ she added. "If you are getting raped, the guy will not have an audience to watch." ${ }^{130}$ A Chief Resident Magistrate confirmed that, in the majority of rape and defilement cases, "there will be no third party witnessing the incident." "Obviously, about corroboration, about the identity of the perpetrator, it is not an easy thing; it is difficult," ${ }^{132}$ she added. A women's rights lawyer in Lilongwe echoed this concern: "Sexual acts are not done in public," she stated, "so it would be very unfair to ask a little child to give you more evidence that what happened to her in private when she was being raped or sexually assaulted." "133 "This rule is not just," she added, "It does not bring justice." 134

An inspector in the Malawi Police Service and a prosecutor at the Child Justice Court explained that the corroboration rule can have especially severe impacts on children who have been raped without any eyewitnesses. ${ }^{135}$ " [A $]$ n offender goes free because there's no corroborative evidence," she said, "yet the child is telling you, 'It's this one who did this

\footnotetext{
${ }^{127}$ Malunga, supra note 5, at 38-39 (quoting a magistrate: "The corroborative evidence of the identity of the accused can be evidence from; eye witnesses, opportunity, that is, where the victim was seen prior or immediately after the incident with the defendant.").

${ }^{128}$ Interview by Darya Vakulenko with a legal intern of a law firm in Lilongwe, Malawi (Mar. 8, 2020) (interview transcript confidential) (on file with the IWHRC).

${ }^{129} \mathrm{Id}$

${ }^{130} I d$

${ }^{131}$ Interview by Amy Uihlein with a Chief Resident Magistrate, supra note 23.

${ }^{132} I d$.

${ }^{133}$ Interview by Darya Vakulenko with a women's rights lawyer, supra note 119.

${ }^{134} I d$.

${ }^{135}$ Interview by Allison Carlon with a prosecutor, Child Justice Court, and an inspector, Malawi Police Service, in Malawi (Mar. 10, 2020) (interview transcript confidential) (on file with the IWHRC).
} 
to me." $" 136$ She recalled a case of a young girl who was raped at night and suffered a fistula ${ }^{137}$ due to the physical trauma of the incident. ${ }^{138}$ "They said, 'It was dark. How did you see that guy?' But [in] this case, it was this one. Even if you meet in the dark, I can recognize you, and you can recognize me. And the magistrate is telling you there's no corroboration - only you. That man was acquitted because there was no corroborative evidence."139

"The laws in Malawi, they favor much the perpetrators," she added. ${ }^{140}$ "They are the ones who are on the safer side than the victims."141 When asked whether the result would have been different had the corroboration rule been absent, she replied, "Yes. That person would be found guilty and convicted and [would have to] face the charges. Only failing to say, 'how did you see that person? It was dark.' Is that the whole reason why someone should go free? I don't think it's justice."142

\section{Penetration}

Prosecutors must also prove, with corroborating evidence, that there was penetration by the man's penis into the victim's vagina in order to show that there was sexual intercourse (or carnal knowledge). ${ }^{143}$ In the seminal case on corroboration from 1966, Mariette $v$. Republic, a rape conviction was overturned and downgraded to attempted

${ }^{136} I d$.

137 "A vaginal fistula is an abnormal opening that connects your vagina to another organ, such as your bladder, colon or rectum. Your doctor might describe the condition as a hole in your vagina that allows stool or urine to pass through your vagina." Vaginal Fistula: Overview, MAYO ClinIC,

https://www.mayoclinic.org/diseases-conditions/vaginal-fistulas/symptoms-causes/syc-20355762 [https://perma.cc/E7V3-B5SB].

${ }^{138}$ Interview by Allison Carlon with a prosecutor, Child Justice Court, and an inspector, Malawi Police Service, supra note 135.

${ }^{139} I d$.

${ }^{140} I d$.

${ }^{141} I d$.

${ }^{142} I d$.

${ }^{143}$ See Mariette v. Republic [1966] 4 ALR Malawi Series 119, 130 (lines 3-5) (High Ct.) (Malawi) ("Nevertheless, the burden rests upon the prosecution to establish penetration beyond all reasonable doubt, and penetration by the male sexual organ, not merely by any part of the male body."). 
rape on appeal because the prosecution could not provide independent evidence that it was the man's penis, and not some other part of him like his finger, that had bruised the girl's labia and ruptured her hymen in two places. ${ }^{144}$ Although the young girl asserted at trial that "she not only felt pain inside her vagina but believed the pain to be caused by his penis," 145 and although the medical technician who examined her indicated that, in his opinion, "the bruises he found on the inner and outer lips could not have been caused by a finger," "146 the court gave the accused "the benefit of the doubt on the nature of the instrument of penetration." 147

The Mariette court's insistence that there be evidence of penile penetration, such as sperm, in the girl's vagina established a precedent that continues to impose a high barrier on victims of unwanted sex in the Malawi judicial system today. ${ }^{148}$ There are many reasons why there might not be evidence of penile penetration, such as a delay in reporting, an inability or unwillingness to get a medical report, the police losing evidence, or the simple fact that there is not always physical evidence of a sexual act. ${ }^{149}$ " [A]fter a rape you are advised to immediately go to police, go to the hospital,", ${ }^{150}$ said a legal intern of a law firm in Lilongwe. "But it is a situation where sometimes you are distraught,

\footnotetext{
${ }^{144} I d$. at 128 (lines 39-41), 129 (lines 5-7).

${ }^{145} I d$. at 128 (lines 38-39).

${ }^{146} I d$. at 129 (lines 5-9).

${ }^{147} I d$. at 130 (lines 5-7) ("The view taken by this court infra gives the appellant the benefit of the doubt on the nature of the instrument of penetration."). The absence of evidence was due to the police losing the evidence. Id. at 131 (lines 5-8).
}

148 But see Katandika v. Republic, [2017] Crim. App. No. 28 of 2017, at 2-3 (High Ct.) (Malawi), https://malawilii.org/system/files/judgment/high-court-generaldivision/2018/63/Charles\%20\%20Katandika\%20\%20\%20-Vs$\% 20$ The $\% 20 \% 20$ Republic $\% 20 \% 20$ Criminal $\% 20 \% 20$ Appeal $\% 20 \% 20 \% 20$ No. $\% 20 \% 20 \% 2028 \% 20 \% 20$ of $\% 2$ 0\%202017.pdf [https://perma.cc/FXW8-PGZV] ("The law is clear that it is not necessary that semen be deposited in the vagina.") ("Emission of seed into the victim is irrelevant.").

${ }^{149}$ A Child Protection Officer at a One Stop Centre in a hospital spoke of a forty-year-old man who wore a condom during his rape of an eleven-year-old girl. "This man was very creative," he said. "He used a condom, thinking that if we did an examination, it wouldn't trace to him. This is what they are doing." Interview by Amy Uihlein with a Child Protection Officer at a One Stop Centre in a hospital in Malawi (Mar. 13,2020 ) (interview transcript confidential) (on file with the IWHRC).

${ }^{150}$ Interview by Darya Vakulenko with a legal intern of a law firm, supra note 128. 
going to the police might not be the first step you take, so you end up not having a police statement, you might not have a medical report," ${ }^{151}$ she explained.

Shame and stigma associated with being sexually violated can weigh heavily on a girl's decision to report, and any delay in reporting can spell death for her case. ${ }^{152}$ "People suffer silently," 153 said a religious leader in the Archdiocese of Blantyre. "Some women would be raped, and they will just keep it to themselves. The problem is with rape, ... in terms of our culture, it brings a kind of shame and stigma on you as someone who was raped. And so, people don't want to live with that." 154 When victims do report after such a delay, he said, "in terms of recall for medical tests, medical watch, all that is gone. In the end, when they say it, nobody believes them." 155 A Chief Resident Magistrate shared this concern for those who report late: "We were saying, someone goes to hospital a week later and we don't have sophisticated equipment, there is no way after a week they can say whether someone had sex or not." ${ }^{\text {156 }}$

151 Id.

152 A lot of times, when a person has been raped, family has to discuss, which is the most ridiculous thing ever! Where a child has been raped, before they even take them to the police, they're like, “Oh! Can we call the uncle?" I'm like, "Why are you having a meeting for an offence like this?" And it's worse still if the relation is close - the father, the ... whoever it is. If it's internal, it's even worse. Then religion also comes into play . ... [O]nce they go to the police, the attitudes of the police .... They will ask you questions about what you're coming to do when you get in ..., out in the open! And if you don't speak loudly . . . . Because, if I come to them to say I'm raped, I'm not going to say [interviewee shouted loudly], "I'm here to report that I was raped!" I'll be speaking [interviewee whispered], "Look, I'm here to report . . .." And the police officers will ask [interviewee shouted loudly], "What are you saying you want in coming here?!"

Interview by Mariame Dangnokho with a High Court Judge, supra note 22.

${ }^{153}$ Interview by Mariame Dangnokho with a religious leader, supra note 35.

${ }^{154} \mathrm{Id}$.

155 Id.

${ }^{156}$ Interview by Amy Uihlein with a Chief Resident Magistrate, supra note 23. 
"There are all sorts of reasons," 157 said the Malawi Country Director of an international organization focused on women and girls' reproductive health. "It could be the kid being defiled today, not knowing it's not right, and then goes to school a week later, tells her best friend. The best friend says, 'Oh, this is wrong, let's go and tell the matron." "158 "I believe in the child's innocence," "159 she added. "It's very, very rare for a child to just come up with this story." ${ }^{160}$ A female official in the Ministry of Gender, Children, Disability and Social Welfare said that the rule was unfair and is impeding access to justice. ${ }^{161}$ "The child might be very, very afraid to tell the parents. She might bathe, the parent might bathe her, and then days go by. And then it's too late for that evidence to really be put forward as evidence, ${ }^{, 162}$ she said.

A medical doctor who has examined victims of sexual violence reiterated the challenges in finding physical evidence of penetration. "In my 20 years of practice," said the OB-GYN, "there's been only . . . maybe two or three times [in] which people have come with the proof that they have been raped. The first thing that they do is to clean themselves up, which is actually deleting the evidence." 163 "So that happens a lot in this country, especially in the rural areas for those who do not know what rape is all about," 164 said the OB-GYN. This barrier became the reality for a six-year-old girl in a rural village outside of Blantyre, who, a senior chief stated, was raped by a man in his forties. "They found [out] after a few days because the girl was unable to walk," 165 she said. "She had

${ }^{157}$ Interview by Mariame Dangnokho with the Malawi Country Director of an international organization focused on women and girls' reproductive health in Lilongwe, Malawi (Mar. 9, 2020) (interview transcript confidential) (on file with the IWHRC).

${ }^{158} I d$.

${ }^{159} I d$.

${ }^{160} I d$.

${ }^{161}$ Interview by Mariame Dangnokho with a female official, Ministry of Gender, Children, Disability and Social Welfare, in Lilongwe, Malawi (Mar. 11, 2020) (interview transcript confidential) (on file with the IWHRC).

${ }^{162} I d$.

${ }^{163}$ Interview by Allison Carlon with an OB-GYN in Mponela, Malawi (Mar. 9, 2020) (interview transcript confidential) (on file with the IWHRC).

${ }^{164} \mathrm{Id}$.

${ }^{165}$ Interview by Allison Carlon with a Senior Chief near Blantyre, Malawi (Mar. 13, 2020) (interview transcript confidential) (on file with the IWHRC). 
[a] fistula ... and now, she's failing to go back to school because ... of trauma. [T]o my disappointment, they went to the police and went to court, and the man was acquitted. They said there was no proof,"

Stakeholders on the front lines of combating sexual abuse against children spoke about the corroboration rule in stark terms. "It's almost a dead case, even for us," a senior manager at Youth Net and Counselling (YONECO), a child advocacy organization that runs a national hotline for reporting sexual abuse against children. "It's almost a dead case because we will say there's no evidence. It becomes tough. We can't explain how it happens, but when it happens, we know the consequences because we have seen the consequences. Some girls have even attempted to commit suicide, because they can't face the same community .... This story of a child has to be believed because, by law, they have to be protected." 168 On whether the abolition of the rule would impact the outcome of their cases, he said, "If that was implemented, we could have won almost every case that we have brought to court on defilement. If that was only implemented." 169

\section{The Woman's Lack of Consent}

Finally, for cases of rape of a female sixteen years or older, ${ }^{170}$ there must also be evidence of a lack of consent on the part of the female victim, and courts usually insist on seeing evidence of a physical struggle, such as scratches, torn clothes, or bruises. ${ }^{171}$ The assumption that such evidence is "easy to get" ${ }^{172}$ disregards the fact that rape oftentimes

\footnotetext{
$166 \mathrm{Id}$.

${ }^{167}$ Interview by Amy Uihlein with a senior manager, YONECO, supra note 84.

${ }^{168} I d$.

${ }^{169} I d$.
}

${ }^{170}$ See the elements for rape in the Penal Code, as amended to Act No. 24, $\S 132$ (2012) (Malawi), https://malawilii.org/mw/consolidated_legislation/701 [https://perma.cc/CH4W-GR98]. Lack of consent is not an element in defilement (statutory rape, i.e., sex with a girl under the age of 16). Id. $\S 138(1)$.

${ }^{171}$ Malunga, supra note 5, at 16 (citing Republic v. Patrick Sambani, Crim. Case No. 392 of 1994: "The evidence of the complainant corroborated by that of her friend who was in her company at the time of the event, her distressed condition, and the condition of her clothes leads to no other conclusion than that the sexual intercourse was without consent."); id. at 37-38.

${ }^{172} I d$. at 38 (quoting a supreme court judge). 
occurs under undue influence, fear, coercion, and threat of physical harm-circumstances that leave no traces of a physical struggle. ${ }^{173}$

In speaking about the gender and power dynamics between men and women in Malawi, a Chief Resident Magistrate said that it is problematic to expect that there will always be physical evidence of a woman's refusal. ${ }^{174}$ "If you are gender sensitive, if you understand power dynamics, if you understand that to overpower does not mean physically overpowering, ... you would be able to appreciate that if somebody says, 'there was no consent,' indeed there was no consent," 175 she explained.

A Child Protection Officer at a hospital One Stop Centre elaborated on some of the reasons why there might not be physical evidence such as bruises and cuts. "There are certain scenarios whereby the woman gives in herself because of fear. So, you won't see any bruises," 176 he said. "Maybe she has been threatened by a knife. Maybe it was a gun. She wouldn't even resist. She would have given in herself." ${ }^{177}$ A Program Officer at Every Girl in School Alliance, an organization that advocates for gender equality through education, said, "If you did not show any evidence of bruising, it does not mean that it never happened." 178

\section{The Corroboration Rule Contributes to a Climate of Fear and a Culture of Impunity}

The corroboration rule, as a barrier to justice for survivors of sexual abuse, not only violates the rights of individual survivors, it also perpetuates a climate of fear for women

\footnotetext{
${ }^{173} I d$. (quoting a state prosecutor: "The question of lack of consent also gives challenges in securing corroborative evidence to it because the offence happen[s] in secret and most of the times the court looks at scratches or signs of struggle which might not be there in some cases due to fear or undue influence which may cause the victim not to struggle and hence in such cases there will be no scratches or bruises to show lack of consent.").

${ }^{174}$ Interview by Amy Uihlein with a Chief Resident Magistrate, supra note 23.

${ }^{175} I d$.

${ }^{176}$ Interview by Amy Uihlein with a Child Protection Officer at a One Stop Centre in a hospital in Malawi (Mar. 13, 2020) (interview transcript confidential) (on file with the IWHRC).

${ }^{177} I d$.

${ }^{178}$ Interview by Darya Vakulenko with a Program Officer, Every Girl in School Alliance, in Lilongwe, Malawi (Mar. 9, 2020) (interview transcript confidential) (on file with the IWHRC).
} 
and girls throughout the country. According to expert studies, the consequences of sexual abuse may include both short and long term physical and psychological harm to the victim, including but not limited to unwanted pregnancies, genital lesions, sexually transmitted infections, post-traumatic stress disorder, fear, lack of trust, shame, guilt, anxiety, depression, drug abuse, self-harm, and suicidal behavior. ${ }^{179}$ Therefore, the importance of obtaining a just result for victims of sexual abuse cannot be overstated.

In a study on survivors' perceptions of justice, when a survivor was asked what justice meant to her, she stated, "'meaningful consequences." 180 "In this context," the study reported, "consequences means there must be an effect or result flowing from the conduct at issue; something must happen to the perpetrator because of their actions."181 As echoed by the UNICEF report, "[s]urvivors are hopeful and encouraged when perpetrators ... are arrested, tried, convicted and sentenced." ${ }^{182}$

On the contrary, a lack of justice for survivors can facilitate additional trauma. One rape victim explained that if her rapist were set free, she would feel like:

[T] he world is a terribly unjust place. It is a place where my life can be irrevocably transformed because a man could exert control, manipulation and violence over me for years without repercussion. It is a

\footnotetext{
${ }^{179}$ ACHPR Guidelines on Combating Sexual Violence, supra note 56, at 17; see also Penelope K. Trickett, Jennie G. Noll \& Frank W. Putnam, The Impact of Sexual Abuse on Female Development: Lessons from a Multigenerational, Longitudinal Research Study, 23(2) Developmental Psychopathology 453 (2013), www.ncbi.nlm.nih.gov/pmc/articles/PMC3693773/ [https://perma.cc/J657-MCNM].

(reporting a twenty-three-year longitudinal study that uncovered that victims experience a variety of long and short term harms "including: earlier onsets of puberty, cognitive deficits, depression, dissociative symptoms, maladaptive sexual development, hypothalamic-pituitary-adrenal attenuation, asymmetrical stress responses, high rates of obesity, more major illnesses and healthcare utilization, dropping out of high school, persistent posttraumatic stress disorder, self-mutilation, Diagnostic and Statistical Manual of Mental Disorders diagnoses, physical and sexual revictimization, premature deliveries, teen motherhood, drug and alcohol abuse, and domestic violence. Offspring born to abused mothers were at increased risk for child maltreatment and overall maldevelopment.").
}

${ }^{180}$ Clare McGlynn \& Nicole Westmarland, Kaleidoscopic Justice: Sexual Violence and Victim-Survivors' Perceptions of Justice, 28 Soc. \& Legal Stud. 179, 186 (2018).

${ }^{181}$ Id.

${ }^{182}$ UNICEF ACCESS TO JUSTICE REPORT, supra note 6, at 30. 
place where my rapist and others like him are enabled at both societal and local levels. 183

In addition, a systemic failure to investigate, prosecute, and punish sex offenders contributes to a culture of impunity for sexual abuse against women and girls. The Executive Director of YONECO stated that "there is a culture of impunity surrounding sexual violence in Malawi. Men are aware that they are extremely unlikely to be punished for sexually abusing girls and women." ${ }^{184}$ And as the CEDAW Committee has noted, such systemic failure "provides tacit permission or encouragement to perpetrate acts of gender-based violence against women." 185

\section{The Corroboration Rule Discriminates Against Female Complainants on the Basis of Sex}

"I do not wish to be duped by the talk of forcing her down. Who doesn't know that women are naturally difficult and pretentious when sex demands are in the fore?",186

The Constitution guarantees equal and effective protection against discrimination on the basis of $\operatorname{sex}^{187}$ and specifies that "[w]omen have the right to full and equal protection by the law, and have the right not to be discriminated against on the basis of their gender.

\footnotetext{
${ }^{183}$ Amber Rose Carlson, Opinion, Is There a 'Rational' Punishment for My Rapist?, N.Y. Times (Oct. 23, 2017) (emphasis added), https://www.nytimes.com/2017/10/23/opinion/rape-punishment-rational.html [https://perma.cc/9ZBP-FZAZ].

${ }^{184}$ Meeting with MacBain Mkandawire, Executive Director, Youth Net and Counselling (YONECO) in Washington, D.C. (Nov. 22, 2019).

${ }^{185}$ CEDAW GR 35, supra note 49, ๆ 24(b).

${ }^{186}$ Rashid Hussein James v. The Republic [2000] Crim. App. No. 12 of 1999 (High Ct.) (Malawi) (cited in The Right to Say No: Marital Rape and Law Reform in Canada, Ghana, Kenya and Malawi 171-72 (Melanie Randall et al. eds., 2017)).

${ }^{187}$ Malawi Constitution, supra note 36, $\S 4$, (“[A]ll the peoples of Malawi are entitled to the equal protection of this Constitution ....."). Furthermore, "[d]iscrimination of persons in any form is prohibited and all persons are, under any law, guaranteed equal and effective protection against discrimination on grounds of $\ldots \operatorname{sex} \ldots . . . I d . \S 20(1)$.
} 
..." ${ }^{188}$ These rights are also guaranteed by CEDAW,${ }^{189}$ ICCPR,,${ }^{190}$ the Banjul Charter, ${ }^{191}$ and the Maputo Protocol. ${ }^{192}$ The discrimination against women and girls on the basis of sex that is inherent to the corroboration rule violates their rights to equality before the law and non-discrimination under the Malawi Constitution and under international law.

\section{A. The Corroboration Rule Is Based on the Unfounded Stereotype that Women and Girls Are Untrustworthy when It Comes to Sex}

The corroboration rule is based on an unfounded stereotype that women and girls will lie about sex, and the rule is applied to the detriment of survivors who are predominantly female. The stereotype that women and girls are apt to lie about sex is empirically invalid, ${ }^{193}$ and a rule borne out of a baseless assumption that women and girls lie about sex is sex-stereotype discrimination that violates the constitution and international law. The corroboration rule denies a woman or a girl the right to have her testimony valued equally to that of the testimony of a male victim or of a victim of any other crime. The Malawi Supreme Court explained in Attorney General v. Malawi Congress Party \& Others that " $[t]$ he concept of equal protection of laws ... implies that among equals the law should be equal and equally administered, that the like should be treated alike

${ }^{188} I d . \S 24(1)$.

${ }^{189}$ CEDAW, supra note 43, art. 2(a) (establishing that States Parties undertake "[t]o embody the principle of equality of men and women ... and to ensure, through law and other appropriate means, the practical realization of this principle....").

${ }^{190}$ ICCPR, supra note 42, art. 3 ("The States Parties . . undertake to ensure the equal right of men and women to the enjoyment of all civil and political rights set forth in the present Covenant.").

${ }^{191}$ Banjul Charter, supra note 40, art. 2 ("Every individual shall be entitled to the enjoyment of the rights and freedoms recognized and guaranteed in the present Charter without distinction of any kind such as . . . sex ... ."); id. art. 3(1) ("Every individual shall be equal before the law.").

192 Maputo Protocol, supra note 41, art. 2(1) ("States Parties shall combat all forms of discrimination against women" and they shall "a) include in their . . . legislative instruments . . . the principle of equality between women and men and ensure its effective application ....").

${ }^{193}$ A. Thomas Morris, The Empirical, Historical and Legal Case Against the Cautionary Instruction: A Call for Legislative Reform, DuKE L.J. 154, 172 (1988). California Chief Justice Wright noted that the cautionary instruction "performs no just function, since criminal charges involving sexual conduct are no more easily made or harder to defend against than many other crimes, and those who make such accusations should be deemed no more suspect in credibility than any other class of complainants." People v. Rincon-Pineda, 538 P.2d 247, 260 (Cal. 1975). A study conducted by the New York Sex Crimes Analysis Unit "found that the incidence of false reports for rape is exactly the same as that for other felonies-about two per cent."

ALLISON \& WRIGHTSMAN, supra note 87, at 205. 
without distinction." 194 The CEDAW Committee has also explained that "[e]liminating judicial stereotyping in the justice system is a crucial step in ensuring equality and justice for victims," and, furthermore, that women and girls who are victims of sex crimes "should be able to rely on a justice system free from myths and stereotypes, and on a judiciary whose impartiality is not compromised by these biased assumptions." ${ }^{195}$ The corroboration rule is precisely such a myth and stereotype, and the use of the rule compromises the integrity and impartiality of the judiciary, resulting in discrimination against women and girls on the basis of sex.

\title{
B. The Application of the Rule Has a Disparate Impact on Women and Girls
}

Not only are survivors of sexual abuse predominantly female persons ${ }^{196}$ but under the Penal Code, two of the most heinous sex crimes (i.e., rape and defilement) are gender specific - the victim is always female, and the perpetrator is always male. ${ }^{197}$ The crimes of rape and defilement require unlawful carnal knowledge of a woman or girl. ${ }^{198}$ The term "carnal knowledge" is defined by Black's Law Dictionary as a term for sexual

\footnotetext{
${ }^{194}$ Attorney General v. Malawi Congress Party \& Others [1997] Civ. App. No. 22 of 1996 (App. Ct.) (Malawi), https://malawilii.org/mw/judgment/supreme-court-appeal/1997/1 [https://perma.cc/76N7-QQXX].
}

${ }^{195}$ CEDAW Committee, General Recommendation No. 28, The Core Obligations of States Parties under Article 2 of the Convention on the Elimination of all Forms of Discrimination against Women, 928 , U.N. Doc. CEDAW/C/GC/28 (Dec. 16, 2010) [hereinafter CEDAW GR 28].

\begin{abstract}
196 See Madison Mellish, Susan Settergren \& Henry Sapuwa, Health Pol’y Project, Gender-Based Violence in Malawi: A Literature Review to Inform the National Response 15 (2015), https://www.healthpolicyproject.com/pubs/436_FINALHPPMalawiGBVLiteratureReview.pdf [https://perma.cc/6WE3-2A89]. Sexual violence against boys is also a serious problem in Malawi. However, the rate of abuse is lower as compared to sexual violence against girls. According to a national survey, one in seven young men had experienced at least one incident of sexual abuse before he turned eighteen years old and one in five young women had experienced sexual abuse before she turned eighteen years old. VIOLENCE Against Children SuRvey, supra note 2, at 23.
\end{abstract}

${ }^{197}$ Penal Code, as amended to Act No. 24, $\S \S 132,138$ (2012) (Malawi).

${ }^{198}$ Id. § 132 (“Any person who has unlawful carnal knowledge of a woman or girl, without her consent, or with her consent if the consent is obtained by force of means of threats or intimidation of any kind, or by fear of bodily harm, or by means of false representation as to the nature of the act, or in the case of a married woman, by personating her husband shall be guilty of the felony termed rape." (emphasis added)); id. §138 ("Any person who carnally knows any girl under the age of sixteen years shall be guilty of a felony." (emphasis added)). 
intercourse, or penetration of a woman's or a girl's vagina by a man's penis. ${ }^{199}$ These sex crimes, therefore, can only be committed by a male person against a woman or a girl, and there exist no mirror provisions in the Penal Code that similarly recognize men and boys as victims of rape or defilement. ${ }^{200}$

A social science researcher based in Zomba stated that, in "all the studies that we've done, violence against women and young girls is quite widespread." 201 "It's like you hear everyday something has happened," ${ }^{202}$ said a professor in Limbe. Many girls are taught to be sexually submissive to men, and "they are influenced to say that they are only there as sexual objects, ${ }^{, 203}$ said a manager at the Centre for Alternatives for Victimized Women and Children. In addition, family economic pressures and women's and girls' financial dependency on men make them extremely susceptible to sexual abuse and coercion. ${ }^{204}$ As a result, the corroboration rule disproportionately impacts women and girls because women and girls comprise the majority share of victims of sexual abuse and because such abuse is rampant.

\footnotetext{
199 See Carnal Knowledge, BLACK’s Law Dictionary OnLine (2d ed. 1910), https://thelawdictionary.org/carnal-knowledge/ [https://perma.cc/WNR7-RYFD]; Sexual Intercourse, BLACK's LAW DiCTIONARY ONLINE (2d ed. 1910), https://thelawdictionary.org/sexual-intercourse/ [https://perma.cc/Z6GW-6DTP].
}

${ }^{200}$ See Penal Code, as amended to Act No. 24, Chapter XV—Offences Against Morality (2012) (Malawi).

${ }^{201}$ Interview by Mariame Dangnokho with a social science researcher, Chancellor College, University of Malawi, in Zomba, Malawi (Mar. 12, 2020) (interview transcript confidential) (on file with the IWHRC).

${ }^{202}$ Interview by Allison Carlon with a professor, Malawi University of Science and Technology, in Limbe, Malawi (Mar. 12, 2020) (interview transcript confidential) (on file with the IWHRC).

${ }^{203}$ Interview by Allison Carlon with a manager, Centre for Alternatives for Victimized Women and Children, in Blantyre, Malawi (Mar. 13, 2020) (interview transcript confidential) (on file with the IWHRC).

${ }^{204}$ Interview by Darya Vakuleno with a secondary school teacher in Lilongwe, Malawi (Mar. 9, 2020) ("Sometimes, because of the issue of the lack of necessities, there is a need. The girl child needs to take care of herself in terms of buying some things like clothes, lotions, and cosmetics. At times, people may take advantage of their needs.") (interview transcript confidential) (on file with the IWHRC). 


\section{The Corroboration Rule Devalues a Sex Crime Victim's Sworn Testimony and Treats Her Testimony Differently than that of a Victim of Any Other Type of Crime Based on a Sex Stereotype}

In general, the Criminal Procedure and Evidence Code does not require a specific number of witnesses to prove any fact. ${ }^{205}$ Once a witness has taken the oath as prescribed in the Oaths, Affirmations and Declarations Act, he or she is deemed competent to "give evidence in a judicial proceeding" in the form of sworn testimony. ${ }^{206}$ Thus, under the statutory laws of Malawi, a single witness's sworn, uncorroborated testimony can be used to convict the accused, unless a statutory exception applies. Such statutory exceptions to this general rule are limited to two specific types of witnesses: accomplices ${ }^{207}$ and very young children. ${ }^{208}$ Only when the witness is an accomplice to the crime or of "immature age" and "does not in the opinion of the court understand the nature of either an oath or an affirmation" will the court determine the testimony to be unsworn and require the testimony be corroborated in order to convict the accused. ${ }^{209}$ Thus, any witness who is not an accomplice and who is fully capable of understanding the nature of either an oath or an affirmation is granted the same evidentiary weight for her sworn testimony without any statutory requirement that her testimony be corroborated by some other material evidence. And furthermore, this testimony alone is sufficient to convict the accused.

\footnotetext{
${ }^{205}$ Criminal Procedure and Evidence Code, No. 14 (2010) $§ 212$ (Malawi) ("Subject to this Code and any other law for the time being in force, no particular number of witnesses shall in any case be required for the proof of any fact."); see also Zgambo v. R [2000] MLR 417 Crim. App. No. 20 of 1999 (C.A.) (Malawi) ("[G]enerally, no particular number of witnesses is required for the proof of any fact: see section 212 of the Criminal Procedure and Evidence Code. A single witness may suffice to prove a case.”).

${ }^{206}$ Oaths, Affirmations and Declarations Act, No. 45 (1967) § 6(1) and Second Schedule (Malawi). The form of the oath is: "I swear by Almighty God that the evidence I shall give shall be the truth, the whole truth and nothing but the truth." The form of the affirmation is: "I do solemnly, sincerely and truly declare and affirm that the evidence I shall give shall be the truth, the whole truth and nothing but the truth." $I d$.

${ }^{207}$ Criminal Procedure and Evidence Code, No. 14 (2010) § 242 (Malawi) (noting that "the court shall take recognizance of the fact that it is unsafe to convict an accused on the uncorroborated evidence of an accomplice....").

${ }^{208}$ See supra note 17.

${ }^{209}$ Oaths, Affirmations and Declarations Act, No. 45 (1967) § 6(1)-(2) (Malawi), https://malawilii.org/mw/legislation/act/1967/45 [https://perma.cc/5536-66WL]; Criminal Procedure and Evidence Code, No. 14 (2010) § 242 (Malawi).
} 
By requiring evidence above and beyond a rape victim's sole testimony, ${ }^{210}$ the corroboration rule places "victims of sexual offences in a special category of suspect witnesses" 211 and this victim's testimony is not "of itself, valuable. It is suspect; and this is essentially because she is a woman or a girl." ${ }^{212}$ For these and other reasons, the corroboration rule was criticized in a recent opinion by Judge Mwale of the High Court of Malawi, who said that the corroboration rule "is unlawful [and] in direct contravention of section 212 of the Criminal Procedure and Evidence Code."213

Moreover, because the corroboration rule requires independent evidence to substantiate the testimony of the victim of a sex crime, the value of her testimony is automatically and irreversibly downgraded - even where the victim is entirely capable of understanding the nature of the oath and affirmation. The corroboration rule, therefore, as applied to victims of sexual abuse, diminishes her testimony to the same level as the testimony of a person of immature age or an accomplice to a crime. This degrading treatment of her testimony is not because she is complicit in the crime like an accomplice or incapable of understanding the nature of the oath or affirmation like a young child. Rather, this degrading treatment is because of an unfounded assumption that female persons are inherently untrustworthy when testifying as the victim of a sex crime. "When viewed against both section 20 of the Constitution and section 212 of the Criminal Procedure and Evidence Code," said Judge Mwale, it is clear that the practice must be "relegated once and for all, to its rightful place which is to non-observance." 214

Courts of law in other countries have also noted the discriminatory effects of the corroboration rule. For example, the Court of Appeal of Kenya noted in one sexual offence case that, "had the charge against the appellant been murder, robbery or any other non-sexual offence the appellant's conviction," which was based on the victim's

\footnotetext{
${ }^{210}$ In a response to the CEDAW Committee, the Malawi representative admitted that the "evidentiary requirement in sexual violence cases remains that the corroboration rule is still required as a matter of practice. ... [T]riers of fact must warn themselves on the dangers of convicting on the uncorroborated evidence of a victim of rape." CEDAW Committee, Replies of Malawi, supra note 8, \ 25.

${ }^{211}$ Ntamnala v. Uganda [2018] Cr. App. No. 34 of 2015 (Sup. Ct.) 4 (Uganda) (Tibatemwa-Ekirikubinza, J., concurring) (invalidating corroboration rule) (quoting Uganda v. Peter Matovu [2002] Cr. Case No. 146 (High Ct.) (Uganda)).

${ }^{212} I d$.

${ }^{213}$ Republic v. Kaliyati [2020] Crim. App. No. 109 of 2018, at 9 (High Ct.) (Malawi).

${ }^{214} I d$. at 10
} 
testimony, "would certainly be held to be sound." 215 The court held that "decisions which hold that corroboration is essential in sexual offences before a conviction are no longer good law" because "treating female witnesses differently in sexual cases" violates the right to non-discrimination in the Constitution of Kenya. ${ }^{216}$ The Indian Supreme Court also concluded that " $[\mathrm{t}] \mathrm{o}$ insist on corroboration except in the rarest of rare cases is to equate a woman who is a victim of the lust of another with an accomplice to a crime and thereby insult womanhood," 217 and "[i]t would be adding insult to injury to tell a woman that her story of woe will not be believed unless it is corroborated in material particulars as in the case of an accomplice to a crime." 218

Furthermore, because the rigid corroboration rule requires that each element of the crime be corroborated by additional evidence to support a survivor's sworn testimony, her testimony is made almost irrelevant to the ultimate conviction of her attacker. Instead, what "is needed is independent evidence confirming the accused's guilt." ${ }^{219}$ In essence, a survivor's testimony is degraded to nothing - it is neither necessary nor sufficient to convict her abuser. The corroboration rule thus discriminates against survivors of sex crimes by diminishing the evidential weight of their testimony-rendering women and girls as persons who are unequal to all others in a court of law.

\section{A Rule with the Purpose and Effect of Discriminating Against Women and Girls Violates Their Rights to Equality and Non-Discrimination}

The corroboration rule discriminates against women and girls on the basis of sex, violating their rights to equality and non-discrimination under the Constitution and international law. The corroboration rule treats the testimony of a female survivor of sexual violence differently than that of a witness in any other type of case, solely because of an unfounded sex stereotype that women and girls might present as "malicious and false witnesses" 220 in cases of rape and defilement. And with a Penal Code that

\footnotetext{
${ }^{215}$ Mukungu v. Republic (2002) 2 E.A. 482 (C.A.K.) (Kenya).

${ }^{216}$ Id.; see also Constitution art. 82 (rev. 1998) (Kenya).

${ }^{217}$ State of Maharashtra v. Chandraprakash Kewal Chand Jain, AIR 1990 SC 658 (1990) (India).

${ }^{218} I d$.

${ }^{219}$ Ndovi, supra note 27, at 25 ("' [I]t can safely be argued that confirmation of the suspect witness's testimony is an irrelevant consideration and that all that is needed is independent evidence confirming the accused's guilt.").

${ }^{220}$ HALE, supra note 9, at 635 .
} 
recognizes only women and girls as victims of some of the most heinous sex crimes (i.e., rape, defilement, and incest), the corroboration rule disproportionately impacts female witnesses in sex offence cases.

The Malawi Supreme Court has interpreted equality to mean that "among equals the law should be equal and equally administered, that the like should be treated alike without distinction." ${ }^{221}$ The CEDAW Committee has also stated that the right to nondiscrimination prohibits any "distinction, exclusion or restriction which has the effect or purpose of impairing or nullifying the recognition, enjoyment or exercise by women of human rights and fundamental freedoms." 222 In its General Recommendation No. 33 on Women's Access to Justice, the CEDAW Committee specifically called on States Parties to:

Abolish any existing laws, procedures, ... and practices that directly or indirectly discriminate against women. . . including: ... [c] orroboration rules that discriminate against women as witnesses [or] complainants . . . by requiring them to discharge a higher burden of proof than men in order to establish an offence ... [and] procedures that exclude or accord inferior status to the testimony of women. ${ }^{223}$

Additionally, the African Commission on Human and Peoples' Rights has also instructed States Parties to prohibit discrimination against victims of sexual violence with respect to rules of evidence; and it has instructed States Parties to "provide for a reversal of the burden of proof such that the victims are not obliged to provide any evidence other than their own statement." 224

The corroboration rule is legally untenable in the face of the new constitutional order and in light of the human rights treaty obligations to which Malawi has committed. Furthermore, not only does the rule discriminate against and impede justice for survivors

\footnotetext{
${ }^{221}$ Attorney General v. Malawi Congress Party and Others [1997] Civ. App. No. 22 of 1996 (App. Ct.) (Malawi), https://malawilii.org/mw/judgment/supreme-court-appeal/1997/1 [https://perma.cc/76N7-QQXX].

${ }^{222}$ CEDAW GR 28, supra note 195, 95 (emphasis added).

${ }^{223}$ CEDAW GR 33, supra note 50, ๆ 25(a)(iii)-(iv) (emphases added).

${ }^{224}$ ACHPR Guidelines on Combating SeXual Violence, supra note 56, at 34 ("This means that, depending on the circumstances, the statement of the victims can be sufficient proof of an act of sexual violence in the absence of any other corroborating evidence (witness statements, documents, medical reports, photos, etc.).").
} 
of sexual violence, it also fuels rape culture throughout the country and grants impunity to sex offenders.

\section{Parliament Should Abolish the Corroboration Rule So That Sexual Offences Are Treated the Same as Every Other Type of Offence}

The legislature should abolish the corroboration rule (including the cautionary instruction) in sexual offence cases because it is an unconstitutional barrier to justice and discriminates against girls and women on the basis of sex. The proposed addition to the Criminal Procedure and Evidence Code would prohibit the use of the rule in sex offence cases due to the nature of the offence and would treat such cases as any other criminal case in Malawi:

244A. Abolishment of the corroboration and cautionary rules.

Notwithstanding any provision of the common law, or any other law or rule of practice, a court shall not treat the evidence of a complainant in criminal proceedings involving the alleged commission of a sexual offence pending before that court with caution and shall not call for corroboration evidence on account of the nature of the offence.

A multitude of stakeholders in Malawi-including magistrates, judges, women's and children's advocates, lawmakers, and community leaders - support the abolition of the corroboration rule, and the High Court has also indicated that the rule may violate the constitutional guarantees accorded to women and girls. In a 2018 High Court case, the Honourable Judge Maclean Kamwambe acknowledged the discriminatory nature of the corroboration rule and advocated for abandoning the practice, recognizing that Malawi is now in a "gender sensitive era and therefore should do away with laws, practices and notions which seem biased in favour of one sex. Such practices [like the corroboration rule] tend to be discriminatory and likely to be unconstitutional if examined closely." 225 This sentiment was echoed by Honourable Judge Fiona Mwale in 2020, who stated that:

In view of [ . . . current Constitutional dispensation, the practice requiring corroboration in sexual offences based on the fact that women are unreliable witnesses, must be called out for what it is. It is discrimination against women based on their sex and or gender and

\footnotetext{
${ }^{225}$ Dyson Nzeru v. Republic, Crim. App. No. 32 of 2018 (High Ct. Principal Registry) (unreported), cited in Republic v. Kaliyati [2020] Crim. App. No. 109 of 2018 (High Ct.) (Malawi).
} 
cannot be sustained. Section 20 of the Constitution expressly forbids discrimination on any ground, including sex. ${ }^{226}$

Judge Mwale concluded that the requirement of corroboration in sexual offence cases "has no place in contemporary legal theory." ${ }^{227}$ Although the portions of the opinions by Judges Mwale and Kamwambe regarding corroboration are dicta and are not essential to the final judgement of each case, such strong signaling from the High Court indicates that individuals and institutions impacted by this discriminatory practice are looking for a cure. In the absence of an imminent opportunity for the Supreme Court of Appeal to consider such a constitutional case, that cure is legislative change.

While abolishing the corroboration rule would remove one barrier for survivors, this step alone certainly would not solve larger, systemic problems of gender stereotyping and judicial bias in the criminal justice system. Sustained sensitization efforts and targeted trainings for all actors in the criminal justice system are needed to counter the pervasive sex discrimination against women and girls. In addition, a large-scale effort would be needed to ensure that relevant stakeholders understand what abolishing the rule would do (and not do). ${ }^{228}$ That is, stakeholders must understand that the change would put survivors of sexual violence on equal footing with other witnesses and victims of other types of crimes. It would not give such survivors an upper hand at trial, nor would it shift the burden of proof to defendants to prove their own innocence. These types of misunderstandings abound in Malawian society, as evidenced by conversations with various interviewees.

Abolishing the corroboration rule would remove a legal barrier that stands in the way of justice and that perpetuates harmful stereotypes in all spheres of the criminal justice system and indeed throughout society. The Parliament of Malawi should uphold women's and girls' fundamental human rights of equality, non-discrimination, and access to justice by abolishing the corroboration rule in sexual offences.

\footnotetext{
${ }^{226}$ Republic v. Kaliyati [2020] Crim. App. No. 109 of 2018, 9 (High Ct.) (Malawi) (emphasis added).

${ }^{227} I d$. at 11 .

${ }^{228}$ Interview by Amy Uihlein with a senior manager, YONECO, supra note 84 ("I would say this is an area where we need to do a lot of awareness and have an understanding. I think we need total awareness around that to see, 'What are we implementing?'").
} 


\section{CONCLUSION}

The corroboration rule is an offensive and discriminatory legal relic that has no place in today's criminal justice system. It obstructs justice for survivors at all stages of the criminal process, leaving women and girls without an effective remedy for the sexual abuse they have suffered and leading to a climate of impunity. It also treats female survivors of sex abuse as a suspect class of witnesses based on an unfounded stereotype about women and girls. The corroboration rule thus violates the fundamental rights of equality, non-discrimination, and access to justice of Malawian women and girls. These rights are guaranteed by the Malawi Constitution as well as a number of international human rights treaties to which Malawi is a State Party. Parliament should amend the Criminal Procedure and Evidence Code so that the use of the rule is banned throughout Malawi. 